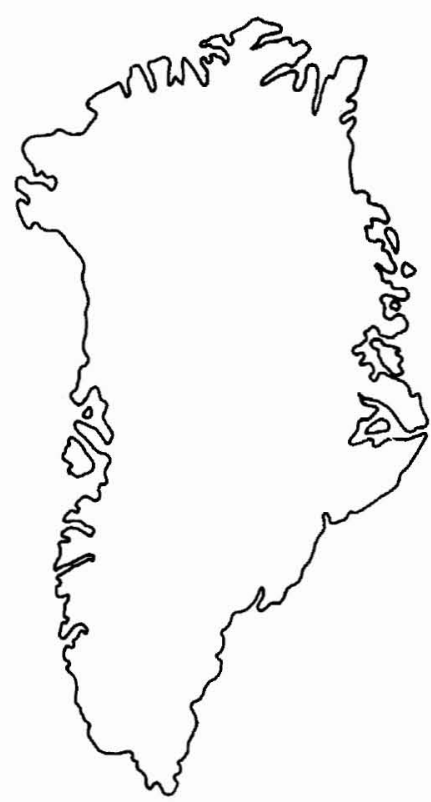

\title{
The Silurian shales of central and western North Greenland: evaluation of hydrocarbon source rock potential
}

\author{
F. G. Christiansen and H. Nфhr-Hansen
}

The Silurian shales of central and western North Greenland form a more than $400 \mathrm{~m}$ thick succession which contains some potential hydrocarbon source rock intervals. Deposition of these organic-rich units was restricted in both time and space and potential source rocks only formed when and where black shales covered wide areas of shallow-water carbonates. Such deposition started in the middle Llandovery in Washington Land and continued thoughout the region in the late Llandovery. Neither the Wenlock nor the Ludlow shales contain sufficient organic matter to be considered as potential source rocks.

The potential source rocks are dominated by oil-prone organic matter (large amorphous kerogen particles, mainly type II) and typically show TOC values between $2 \%$ and $6 \%$. The generative potential of immature to early mature samples is high with values up to $30 \mathrm{mg} \mathrm{HC/g}$ rock.

A drastic increase in thermal maturity of surface rocks is observed from south to north and most of the potential drainage area is thermally mature to postmature. This leaves only few chances of finding trapped hydrocarbons sourced by Silurian shales in North Greenland.

F. G. C. \& H. N.-H., Geological Survey of Greenland, Øster Voldgade 10, DK-1350 Copenhagen $K$, Denmark.

Organic-rich limestone, carbonate mudstone, and shale of potential source rock quality mainly occur in two geological settings in North Greenland: a Cambrian shelf sequence and a Silurian slope sequence (Christiansen et al., 1985). The Cambrian, including the particularly interesting Henson Gletscher Formation, was described by Christiansen et al. (1987) with respect to sedimentary facies, organic richness and quality, thermal maturity, and the hydrocarbon potential.

The present paper attempts a detailed investigation of the geographical and stratigraphical constraints in source rock parameters of shales within the Silurian slope sequence. All available screening data (LECO, Rock Eval, optical studies of kerogen concentrates) are presented, employing a regional and litho/biostratigraphical framework which allows a consistent differentiation of analytical parameters. The thermal maturity pattern is evaluated with the construction of maps showing the regional variation of the two maturity parameters $T_{\max }$ (from the Rock Eval) and TAI (Thermal Alteration Index).
This study presents results originating from the 'Nordolie' project, a programme designed to investigate the presence, distribution and thermal maturity of potential hydrocarbon source rocks in central and western North Greenland (Christiansen \& Rolle, 1985).

\section{Regional setting and stratigraphy}

The Lower Palaeozoic sediments of North Greenland were deposited within the eastern extension of the Franklinian basin of Arctic Canada (Trettin \& Balkwill, 1979 ) and occur in a series of east-west striking facies belts (fig. 1) (cf. Higgins et al., in press). In the south, Cambrian to Silurian shelf sediments flank Precambrian crystalline basement of the Greenland shield which only outcrops in south-east Wulff Land in the study area (fig. 1). A sequence of mainly shallow-water marine carbonates, at least $3 \mathrm{~km}$ thick, forms a $100 \mathrm{~km}$ wide area immediately north of the basement areas. Cambrian to Silurian deep-water basin sediments outcrop north of 


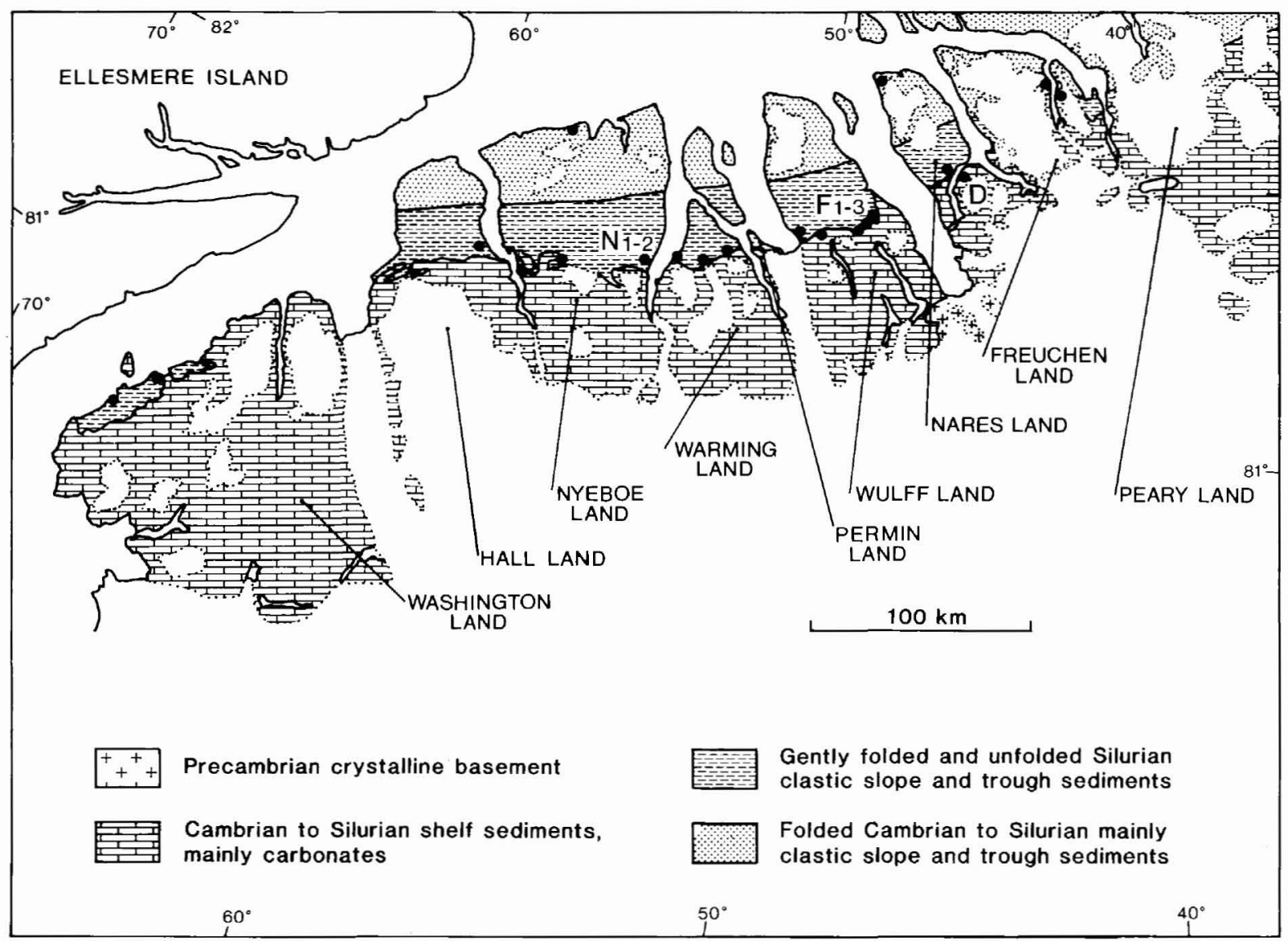

Fig. 1. Camps (dots) and drill sites (letters) during the study of the Silurian shales in the 1984 and 1985 field seasons. The map is modified from Dawes (1976).

the shelf sequence and consist of up to $8 \mathrm{~km}$ of mostly sandstone turbidites with some shales, conglomerates and cherty shales.

The facies transition between the shelf carbonates and the deep-water siliciclastics in the more rapidly subsiding trough to the north was controlled by eastwest trending tectonic lineaments (Surlyk \& Hurst, 1984; Higgins et al., in press). In the Early Silurian the Navarana Fjord escarpment (Surlyk \& Hurst, 1983, 1984; Surlyk \& Ineson, 1987; Escher \& Larsen, 1987) separated shelf carbonate deposition to the south from turbidite deposition to the north. In late Llandovery time the outer platform drowned and the trough, filled to the brim with turbidites, expanded southwards to a newly established shelf-trough boundary defined by a reef belt. In the Wenlock to Pridoli, deep-water deposition took place in most of what is now North Greenland with the exception of a few isolated reefs.

The Silurian shales, which are the subject of the present source rock study, were deposited during this phase of basin expansion. Lithostratigraphically, the Silurian deep-water siliciclastics and the shallow-water carbonates are assigned to the Peary Land Group (Hurst, 1980; Hurst \& Surlyk, 1982; Larsen \& Escher, 1987) and the Washington Land Group (Hurst, 1980; Sønderholm et al., 1987), respectively (fig. 2A). The following units have been included in the source rock study: the Cape Schuchert Formation (only known in Washington Land), the Lafayette Bugt Formation, the Wulff Land Formation with the Thors Fjord, Hand Bugt and Repulse Havn Members, all from the Peary Land Group, and the Kap Lucie Marie Formation (only known in Washington Land) of the Washington Land Group.

Folding and heating of the northern part of the region took place during the Ellesmerian orogeny in late Devonian or early Carboniferous (Dawes, 1976; Higgins et al., 1982). The southerly, only weakly deformed, region was probably thermally affected during this episode (Christiansen et al., 1987).

Upper Palaeozoic and Mesozoic sedimentation, corresponding to the Sverdrup basin in the Canadian Arctic (Balkwill, 1978) or the Wandel Sea basin in eastern 
A

N

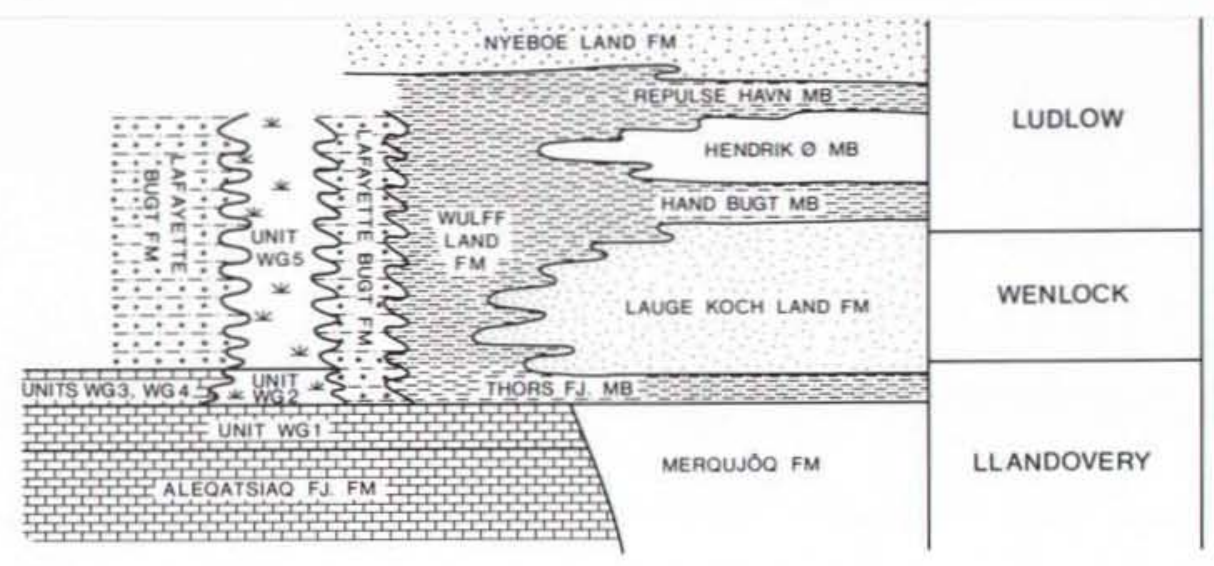

B

$\mathrm{s}$

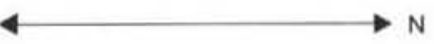

Fig. 2. A: stratigraphic nomenclature of the Silurian sediments in the Hall Land to Freuchen Land region. WG: Washington Land Group. Based on Hurst \& Surlyk (1982), Larsen \& Escher (1987) and Sønderholm et al. (1987). B: classification of studied shales into groups.

North Greenland (Håkansson \& Stemmerik, 1984), is not recorded from the area studied.

Late faulting and dyke intrusion occurred during Eurekan events in the late Cretaceous to early Tertiary (Soper et al., 1982); within the study area basic dykes were observed in Silurian shales in the Freuchen Land region.

\section{Silurian shales}

Analytical work was performed on samples collected during a major reconnaissance programme in 1984 (Christiansen \& Rolle, 1985; Christiansen et al., 1985) followed by detailed studies and shallow core drilling in the summer of 1985 (Christiansen et al., 1986). A small number of samples from Washington Land, collected and described by Norford (1972) and Hurst (1980), were included in the study.
The Silurian shales were studied from 17 field camps. Six drill holes penetrated representative intervals of the various shale units (fig. 1). The shales are well exposed throughout the region (figs 3 and 4). Fig. 5 summarizes the field data of the area studied and briefly outlines the outcrop and subcrop pattern of the Silurian shales. A number of key areas provide information on the distribution of shale units, a rough estimate of the thickness, and also indicate the spatial relations to underlying, overlying and interdigitating sandy turbidites and carbonates. The folded Silurian shales in the northern part of the region have not been systematically studied due to their high thermal maturity (Christiansen et al., 1985).

The source rock parameters are presented within a combined bio- and lithostratigraphic framework (fig. 2B), which allows a consistent differentiation of parameters like content of organic carbon. 


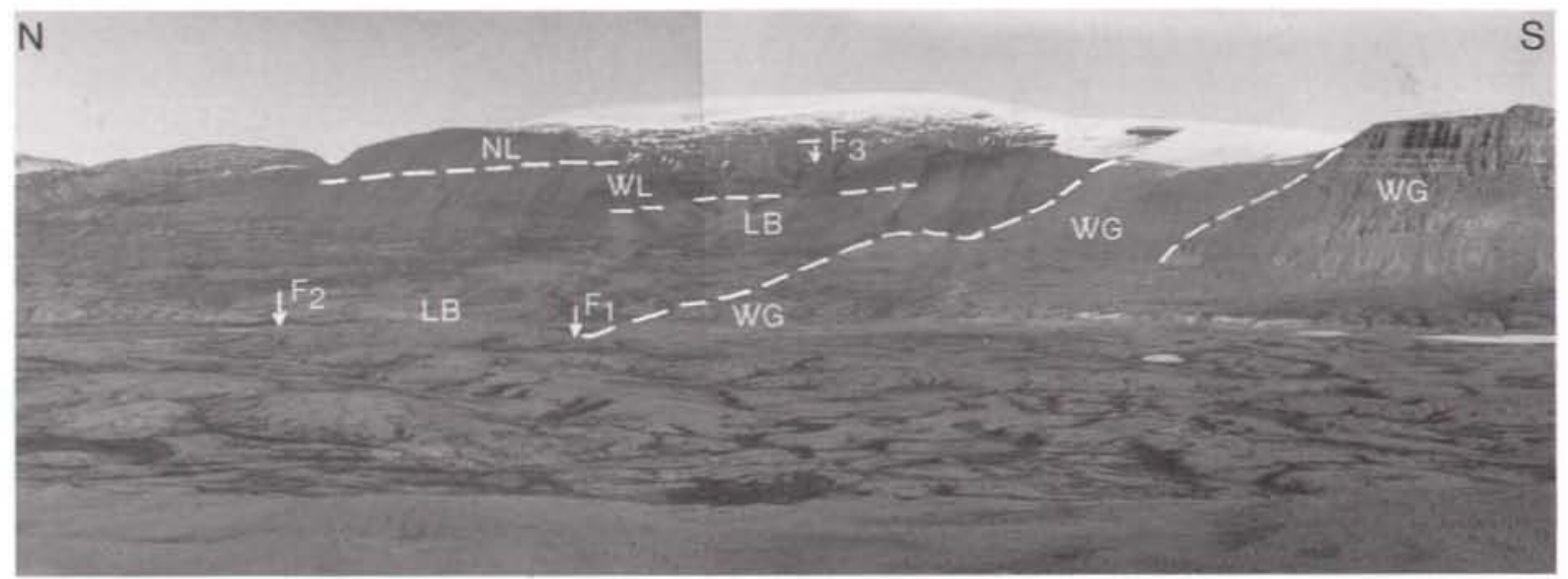

Fig. 3. Typical exposure of the Silurian shales in contact with Silurian shallow-water carbonates in central Wulff Land. NL: Nyeboe Land Formation, WL: Wulff Land Formation, LB: Lafayette Bugt Formation, WG: Washington Land Group. $\mathrm{F}_{1}, \mathrm{~F}_{2}, \mathrm{~F}_{3}$ : drill sites. See fig. 5 for details of location and measured sections. Height of cliff is approximately $800 \mathrm{~m}$.

Four groups of shale have been discerned; two of these (A and B) correspond, respectively, to the lower and upper part of the middle to late Llandovery shales which overlapped the drowned Navarana Fjord escarpment. The group $\mathrm{C}$ shales comprise all the slope and trough floor shales of Wenlock and Ludlow age, whereas group D includes undifferentiated 'back-reef' shales and lime mudstones.

Fig. 6 summarizes the age relations and cumulative thickness of shale and lime mudstone of the four groups regionally.

Group A. The lower part of the Thors Fjord Member of the Wulff Land Formation and the age equivalent part of the Lafayette Bugt Formation (middle to late Llandovery). The Cape Schuchert Formation in Washington Land has also been included in this group.

Group B. The upper part of the Thors Fjord Member of the Wulff Land Formation and the age equivalent part of the Lafayette Bugt Formation (late Llandovery to (?) early Wenlock).

Group $C$. The middle and upper part of the Wulff Land Formation (including the Hand Bugt and Repulse Havn Members) and the age equivalent part of the Lafayette Bugt Formation (early Wenlock to middle Ludlow).

Group D. Undifferentiated 'back-reef' shales and lime mudstones from the Lafayette Bugt Formation (and the comparable Kap Lucie Marie Formation) in Hall Land and western Nyeboe Land with a range in age from late Llandovery to (?) early Ludlow.

\section{Group A shales}

Group A shales are well exposed in Nares Land and in Washington Land and scattered outcrops occur close to the present-day sea level in central Wulff Land, Permin Land, Warming Land, and eastern Nyeboe Land (figs 5 and 6). The shales are dark or black and finely laminated, often with a fissile and friable appearance. Freshly broken pieces frequently have a petroliferous odour.

The lower boundary of the group A shales is easily defined where black or greenish shales, occasionally with calcarenites, conformably overlie pale, massive platform carbonates of either Unit WG 1 (Washington Land Group) or the Aleqatsiaq Fjord Formation (Morris Bugt Group) (Peel \& Hurst, 1980; Sønderholm et al., 1987). The upper boundary with group $B$ is only tentatively recognized as a change to shales of slightly paler colours and often corresponds to the incoming of metre thick sandstone turbidites. The cumulative shale thickness is approximately $40 \mathrm{~m}$ throughout the study area (fig. 6). In Washington Land the shale seems thicker but is probably not greater than $100 \mathrm{~m}$.

A very rich and diverse graptolite fauna is recorded in most places. From Nyeboe Land to Nares Land the spiralis Zone of late Llandovery age is everywhere present. Locally the base of the group A shales occurs in the turriculatus Zone (Hurst \& Surlyk, 1982; Larsen \& Escher, 1985). In Washington Land all shales collected have been included in group A. A broad range in age of the analysed samples is recognized with the argentus 

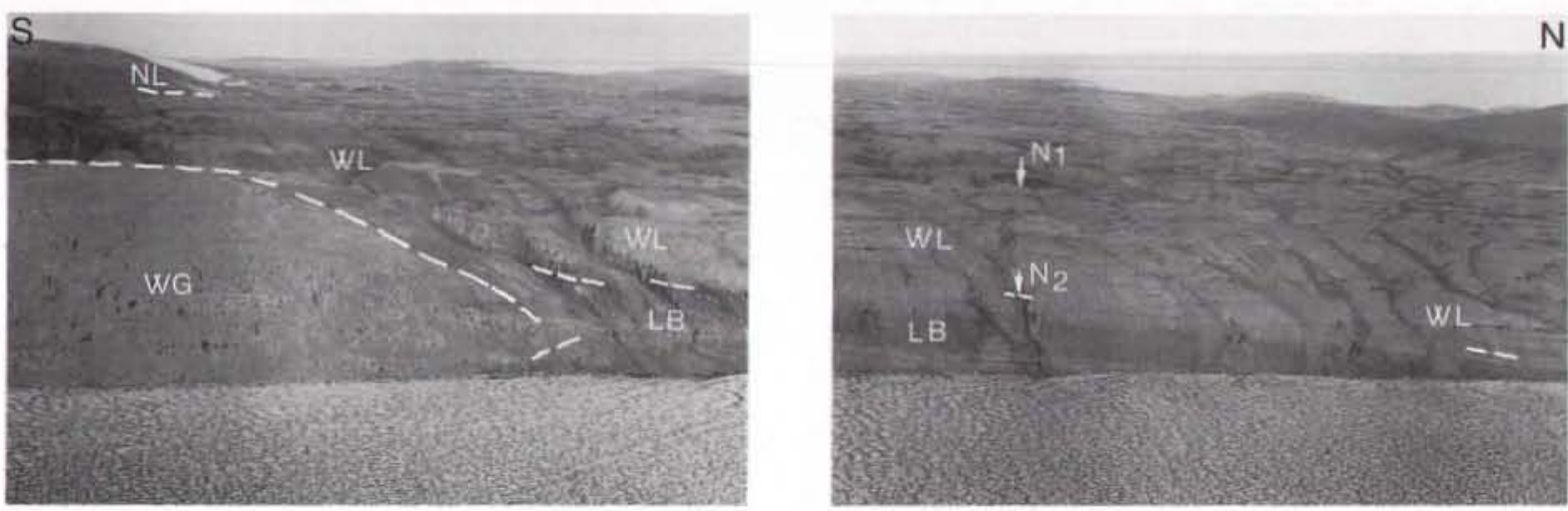

Fig. 4. Typical exposure of Silurian shales in contact with Silurian shallow-water carbonates in eastern Nyeboe Land. NL: Nyeboe Land Formation, WL: Wulff Land Formation, LB: Lafayette Bugt Formation, WG: Washington Land Group. $\mathrm{N}_{1}, \mathrm{~N}_{2}$ : drill sites. See fig. 5 for details of location and measured sections. Height of cliff is approximately $600 \mathrm{~m}$.

Zone, the convolutus Zone, the turriculatus Zone, and the spiralis Zone of middle to late Llandovery age being reported (Hurst, 1980; Bjerreskov, 1981) (fig. 6).

The lower part of the Thors Fjord Member is represented by two cores ( $D$ and $F_{1}$ ) which penetrate the boundary to the underlying platform carbonates.

Core $\mathrm{F}_{1}$ exhibits a heterolithic sequence of alternating wavy laminated muddy shale/lime mudstone and calcarenite/calcirudite (appendix). The fine-grained units constitute less than $20 \%$ in volume, mainly in the upper part. The shale laminae or layers are typically a few millimetres thick, rarely more than a few centimetres. The calcarenites (to calcirudites) are usually homogeneous and structureless and 1 to $5 \mathrm{~cm}$ thick. A number of beds thicker than $20 \mathrm{~cm}$ are indicated on the logs (appendix). These units are often coarse grained with carbonate clasts or occasionally mudflakes exhibiting slump features.

Core D consists of a shale sequence deposited on top of Unit WG-1 shelf carbonates. Finely laminated black shale forms the lower part. Graded $1 \mathrm{~mm}$ to $1 \mathrm{~cm}$ thick calcarenites are common in this part, although they form less than $10 \%$ in volume. Elongated centimetre long calcareous concretions and millimetre large pyrite aggregates occur throughout this level. The upper part of the core is dominated by grey to dark grey, occasionally greenish, silty shale with a well defined parallel lamination. Fine-grained grey sandstone turbidites, either homogeneous or poorly laminated, are frequent and range in thickness between 10 and $50 \mathrm{~cm}$.

\section{Group B shales}

Group B shales were studied in the same areas as those of group A from eastern Nyeboe Land to Nares Land (figs 5 and 6 ). The shales are dark grey to black, finely laminated and have a strong resemblance to the underlying group $\mathrm{A}$ shales. The graptolite fauna is rich and diverse, comprising the upper part of the spiralis Zone and/or the sakmaricus-laqueus Zone of the late Llandovery and may reach the early Wenlock (fig. 6). The boundary with the overlying group $\mathrm{C}$ shales is recognized as a transitional colour and grain size change from a predominantly dark or black shale to a mainly grey silty shale. This boundary often coincides with interfingering of several metre thick sandstone turbidites of the Lauge Koch Land Formation. The cumulative shale thickness of group B is between 40 and 100 $\mathrm{m}$, averaging approximately $75 \mathrm{~m}$.

The two cores $F_{2}$ and $N_{2}$ into shales of group $B$ represent two rather different types with $\mathrm{F}_{2}$ dominated by fine-grained siliciclastic sediments and $\mathrm{N}_{2}$ having a strong input of carbonates. The $\mathrm{F}_{2}$ core comprises homogeneous finely laminated black muddy shale which is very rich in graptolites. Occasionally, starved ripples with millimetre-thick calcarenites occur. Calcarenites or conglomerates with thicknesses from a few up to $20 \mathrm{~cm}$ are occasionally observed. The lithologically variable $\mathrm{N}_{2}$ core forms a heterolithic sequence of black muddy shale and carbonates in approximately equal amounts. Homogeneous black shale rarely forms units thicker than $5 \mathrm{~cm}$ and even the most shale rich parts 


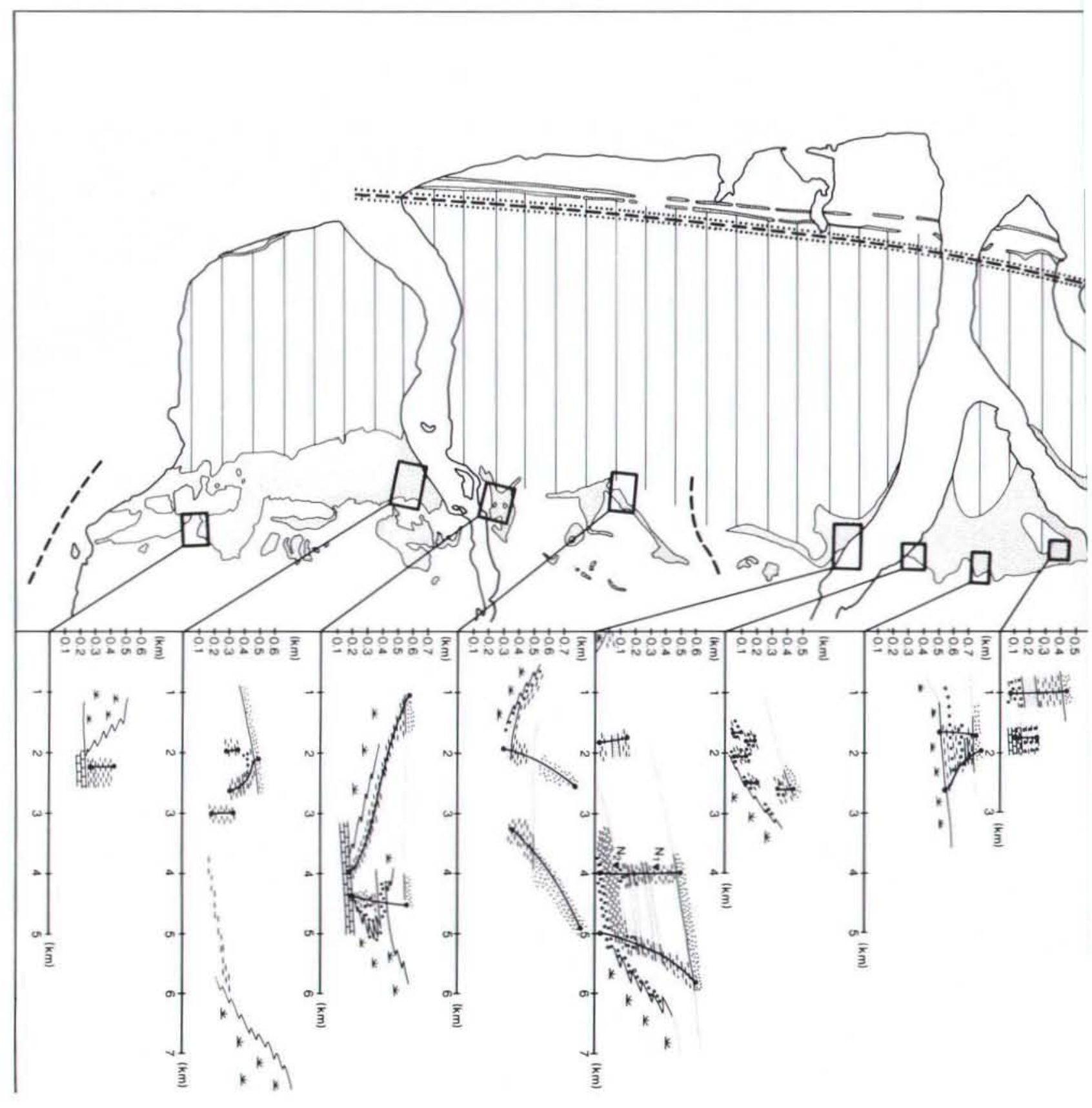

MAP

Key area

Subcrop of Silurian shale

Fig. 5. Outcrop and subcrop pattern of Silurian shales in the Hall Land to Freuchen Land region. Based on mapping by the Geological Survey of Greenland (Henriksen, 1985, 1987). Schematic $\mathrm{N}-\mathrm{S}$ section is shown for each key area.

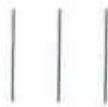

Subcrop of Silurian shale

Outcrop of Silurian shale

Himintir Trace of Navarana Fjord Escarpment (from Escher \& Larsen, 1987) 


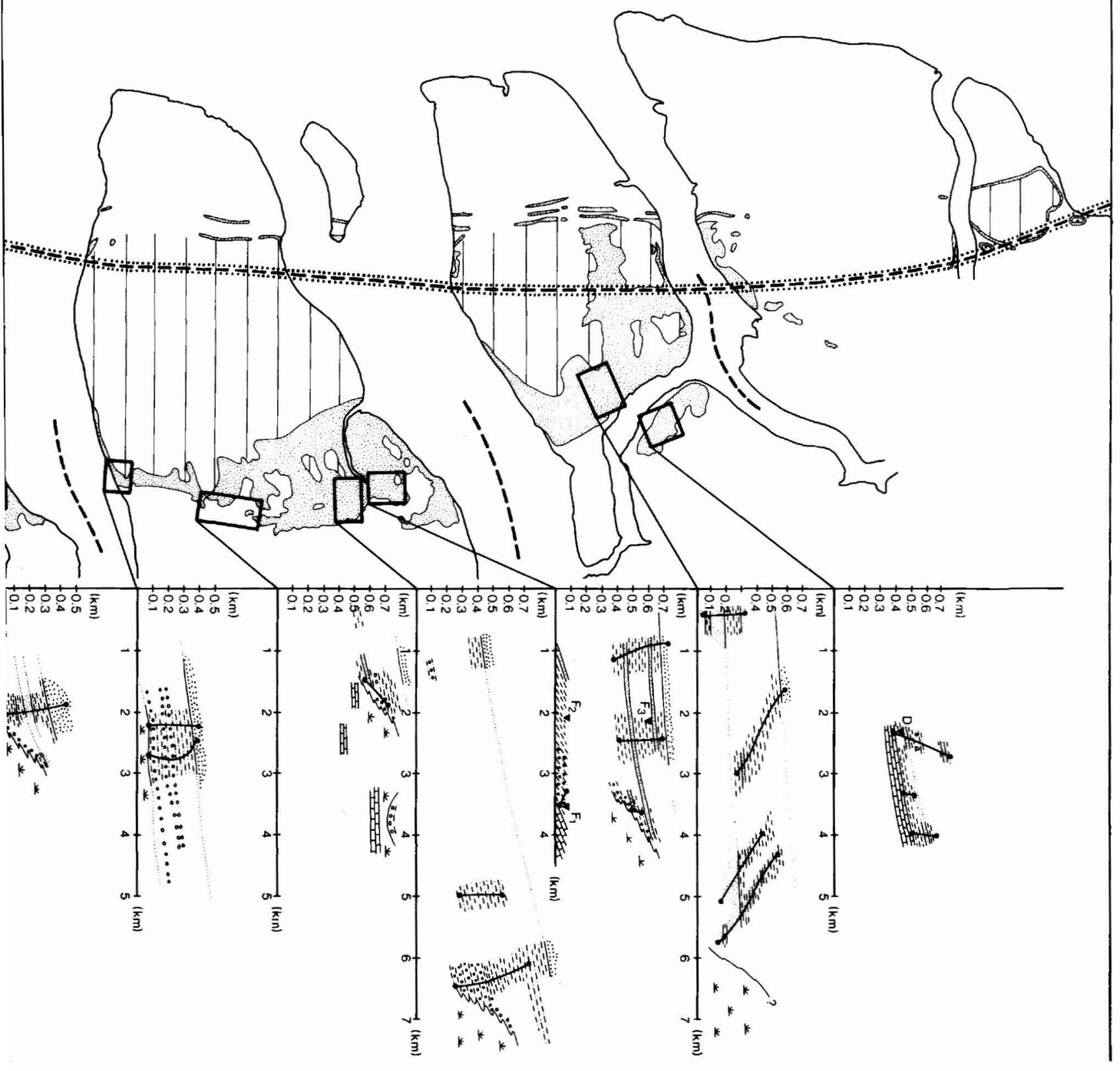

PROFILES

Sandy turbidites (Nyeboe Land Fm)

Sandy turbidites (Lauge Koch Land Fm)

Silty shale (Wulff Land Fm)

Muddy shale ( Thors Fjord Mb)

Conglomerate (Lafayette Bugt Fm)
采 Carbonate build-ups (Units WG2, WG5)

卧卧 Shelf carbonates (Units WG1, WG3, WG4)

Measured section

- $F_{3} \quad$ Drill site 


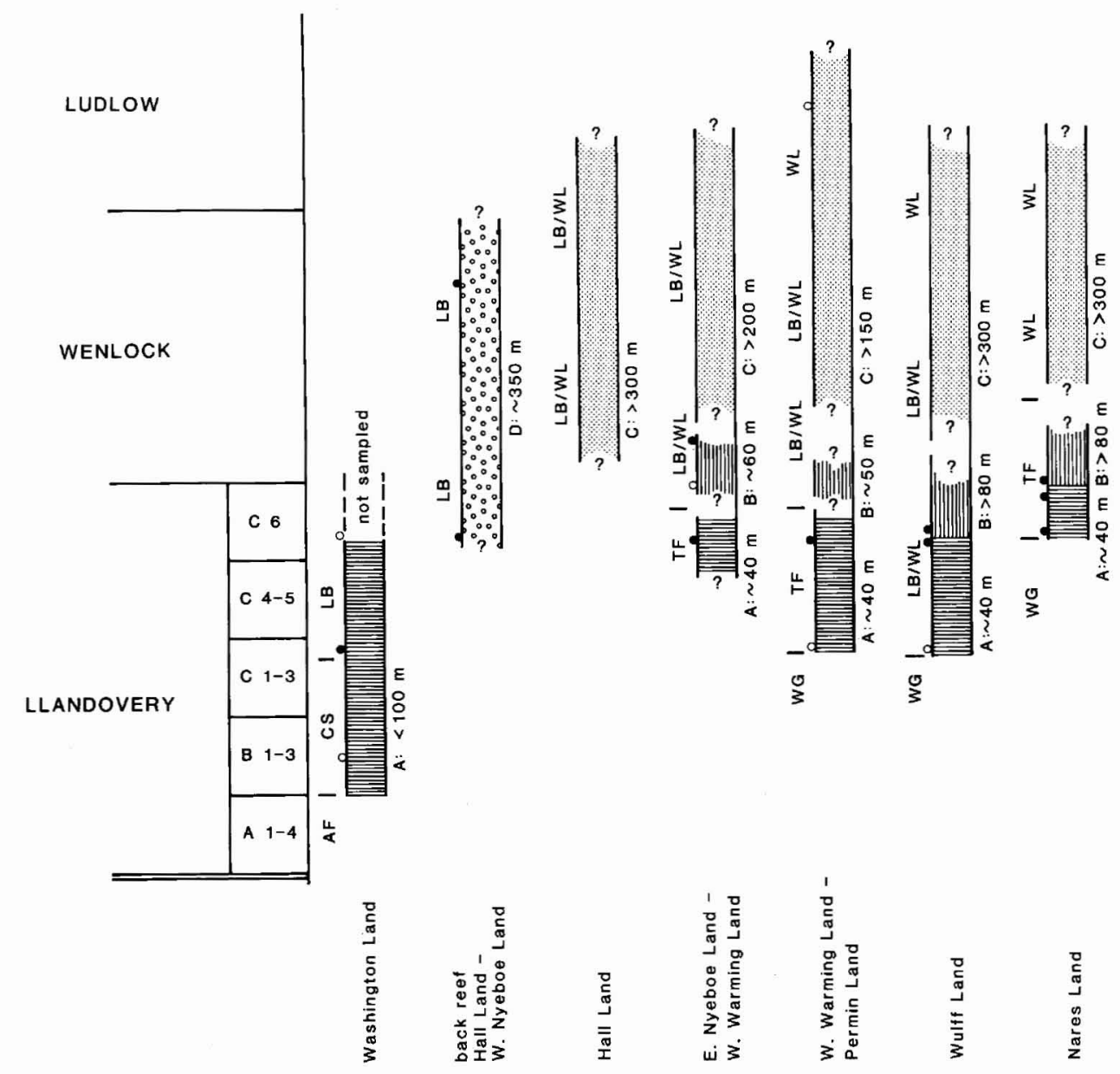

Fig. 6. Stratigraphic and geographic distribution of the investigated shale groups (A: horizontal hatching, B. vertical, C: small dots, D: circles). Age relations are based on graptolite determinations by Bjerreskov (1981, 1986 and unpublished data). The filled and open dots on the section margins indicate identification of graptolite zones based on the studied samples and on other available data, respectively. The thickness of the four groups is estimated cumulative thickness of shale and lime mudstone (possible source rocks). See fig. 5 for details of location and measured sections. AF: Aleqatsiaq Fjord Formation, CS: Cape Schuchert Formation, LB: Lafayette Bugt Formation, TF: Thors Fjord Member, WG: Washington Land Group, WL: Wulff Land Formation.

contain numerous 1 to $5 \mathrm{~mm}$ thick normal-graded finegrained calcarenites. In the central part of the core black mudstone occurs as matrix in pebbly mudstone to mud-supported conglomerate.

\section{Group C shales}

By far the greater part of the outcrop of Silurian shales belong to group $\mathrm{C}$ which can be continuously studied from Hall Land to Peary Land (figs 5 and 6). The shales are dark grey to pale grey, occasionally greenish in colour. Silty shale dominates and is often recognized as thin $\mathrm{Te}$ turbidites with starved ripples.
Some intervals are bioturbated. The graptolite fauna is generally poor but rare graptolite assemblages covering most zones from middle Wenlock to middle Ludlow have been reported, suggesting a continuous period of deposition. The cumulative thickness of shale in group $\mathrm{C}$ is between $200 \mathrm{~m}$ and $400 \mathrm{~m}$, averaging approximately $300 \mathrm{~m}$.

The two drill cores $\mathrm{F}_{3}$ and $\mathrm{N}_{1}$ through group $\mathrm{C}$ shale are very similar. The $\mathrm{N}_{1}$ core comprises homogeneous dark silty shale with a well defined parallel lamination. Only few starved ripples with centimetre thick turbidites occur and no calcarenites are reported. The $F_{3}$ core is dominated by dark grey silty shale (paler than 
$\mathrm{N}_{1}$ ) and exhibits a well defined parallel to wavy lamination. Starved ripples with pale coarse siltstone or fine sandstone are common throughout the core. There is some evidence of bioturbation.

\section{Group D shales}

In the present study it has not been possible to make a chronological subdivision of the back-reef shale sequence in western Nyeboe Land and across Hall Land. Only one continuous section has been studied, together with a number of reconnaissance localities (figs 5 and 6). The dark, fine-grained sediments are rich in carbonate, and both lime mudstone and lime siltstone are common. These rock types are characterized by a buffyellow weathering colour and the presence of numerous carbonate concretions. The graptolite fauna is rich and relatively diverse; a large number of graptolite zones are present covering the age span from late Llandovery to early Ludlow. The thickness of the back-reef shales and lime mudstones is approximately $350 \mathrm{~m}$ in western Nyeboe Land (figs 5 and 6); in Hall Land it is at least $200 \mathrm{~m}$ but probably close to the value from Nyeboe Land.

\section{Analytical results}

Preliminary geochemical analyses (LECO, Rock Eval) have been carried out in the source rock laboratories of the Geological Survey of Denmark and the Geological Survey of Greenland, and in addition optical studies have been carried out on kerogen concentrates. The techniques employed and sample preparation methods are described in detail by Christiansen et al. (1985).

\section{Carbon content}

All LECO analyses are shown in TOC-TIC diagrams divided regionally for the four main groups (fig. 7). The TIC value (Total Inorganic Carbon) reflects the content of carbonate minerals and thus provides information on the relative importance of carbonate versus siliciclastic deposition. The TOC (Total Organic Carbon) content may be applied as a first approximation of the source rock potential.

The group A shales in Nares Land (including core D) have a high content of organic carbon with an average of $2.84 \%$ and many values close to $5 \%$. The influence of carbonate sedimentation was low. In contrast, carbonate sedimentation dominated in Wulff Land (including core $F_{1}$ ). Here the TOC values average close to $2 \%$. In the region between Permin Land and eastern Nyeboe Land the few analysed group A shales display TOC values between 1.5 and $3 \%$ with low contents of carbonate. In Washington Land, the sampled group $\mathrm{A}$ shales exhibit highly scattered values of both TOC and TIC. Some of the samples are very rich in organic matter with TOC values of more than $5 \%$.

The group B shales in Nares Land have a low content of organic matter compared to the group A shales and a similarly low carbonate content. In Wulff Land there is little difference in TOC values between groups A and $B$, although there is a considerable difference in carbonate content from base to top (compare cores $\mathrm{F}_{1}$ and $\mathrm{F}_{2}$ ). Also in the Permin Land to Nyeboe Land region the TOC values of group B are only slightly lower than those of group A. The carbonate content of the group B shales is low in Nares Land and Wulff Land but high in the Permin Land to Nyeboe Land region.

The group $\mathrm{C}$ shales (including cores $\mathrm{F}_{3}, \mathrm{~N}_{1}$ ) everywhere show TOC contents below $2 \%$ and in the majority of cases below $1 \%$. The average values in the studied region vary from $0.67 \%$ to $0.92 \%$. The carbonate content is generally very low, with the exception of the reef-dominated Hall Land region.

In Hall Land and western Nyeboe Land, the group D samples contain between $1 \%$ and $2 \%$ organic carbon whereas the carbonate content is highly variable, although often high.

In summary, the TOC analyses suggest that only the group A shales are sufficiently rich in organic matter to be considered a good potential source rock, with an initial TOC average close to $3 \%$ and some intervals in excess of $5 \%$. Group B has some intervals with 2 to $3 \%$ TOC and therefore has a minor potential. The TIC analyses indicate regional variations in the influence of carbonate deposition in the Silurian shales throughout late Llandovery - early Ludlow times.

All of the analyses mentioned above are from samples of shales close to the Silurian reef belt. The Thors Fjord Member, occurring on the north coast of Hall Land, was also deposited on platform carbonates. It gives TOC values above $2 \%$ and is comparable with the remaining region except for its high thermal maturity.

Few analyses of the distal, and now thermally postmature, representatives of the Thors Fjord Member have been made. These grey shales are sandwiched between the sandstone turbidites of the Merqujôq and Lauge Koch Land Formations and record values below 1\% TOC. This indicates strong dilution, or different preservation conditions, of the organic material in shales north of the Navarana Fjord escarpment. 

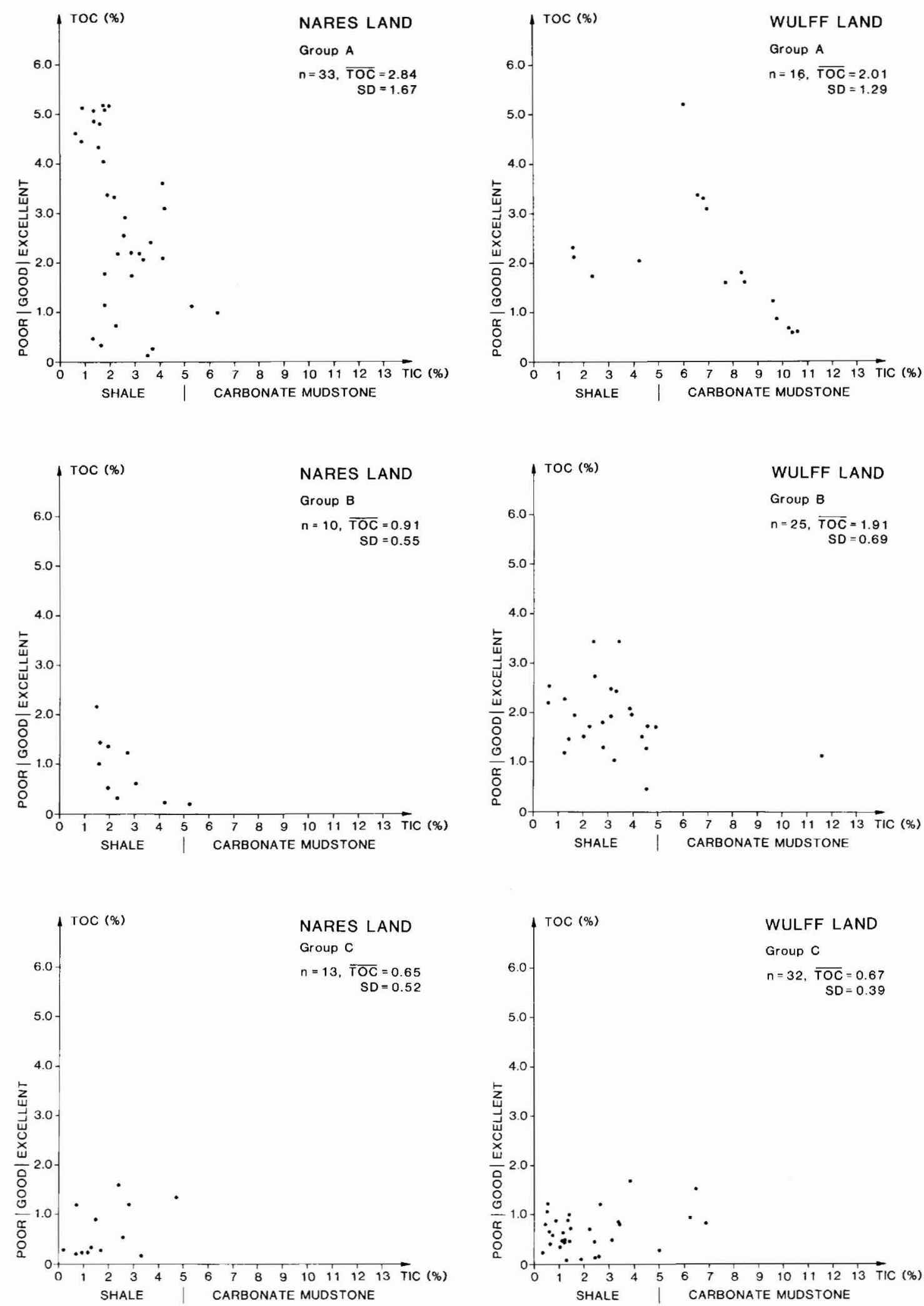

Fig. 7. Plots of Total Inorganic Carbon (TIC) versus Total Organic Carbon (TOC) for the various shale units regionally. Number 

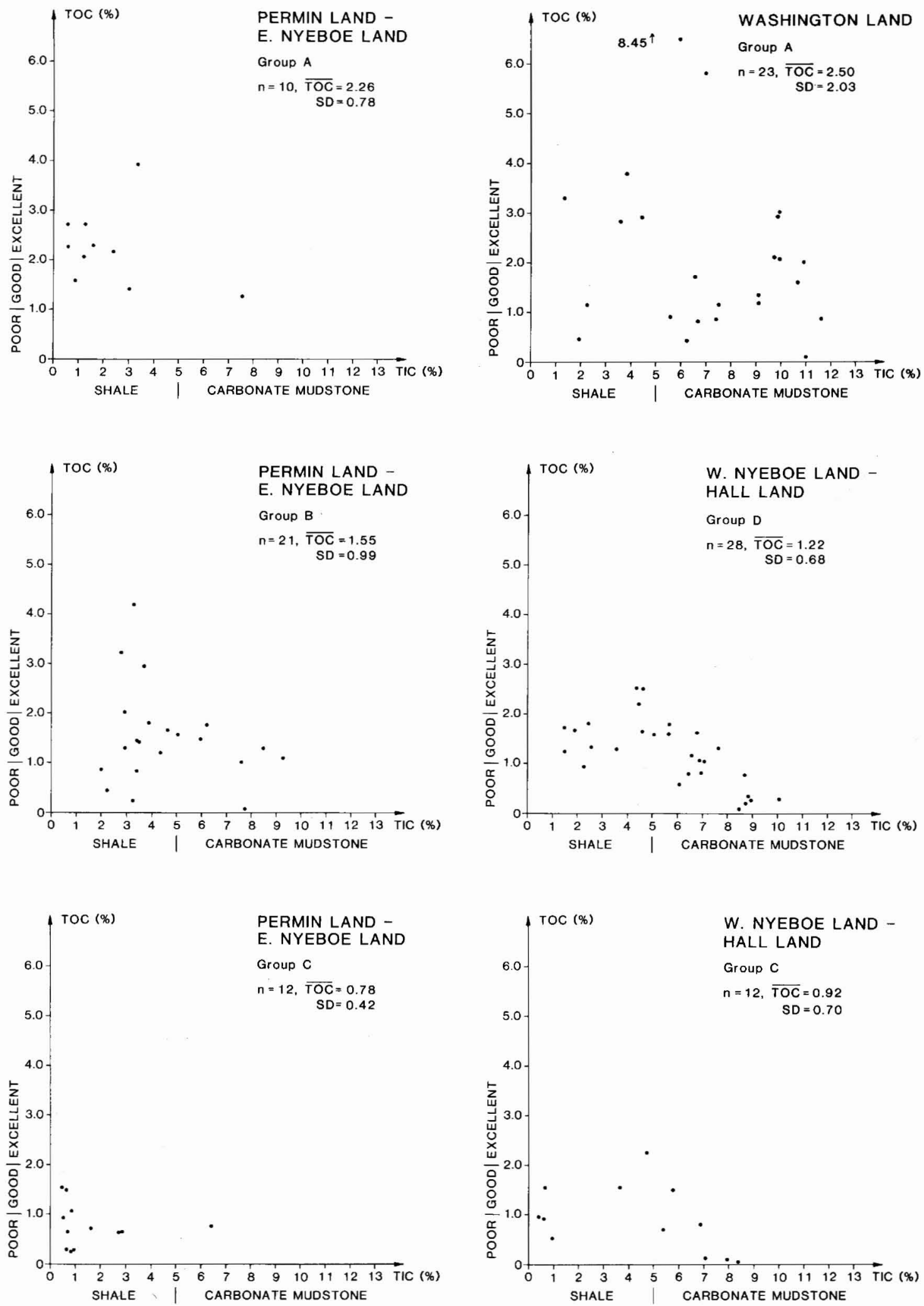

of samples, average and standard deviation of Total Organic Carbon are indicated for each plot. 


\section{Optical kerogen study}

Optical studies have been carried out on kerogen separated by standard palynological preparation. Inorganic matter was dissolved by acid treatment $(\mathrm{HCl}$ and $\mathrm{HF})$, the remaining kerogen was studied in a non-sieved
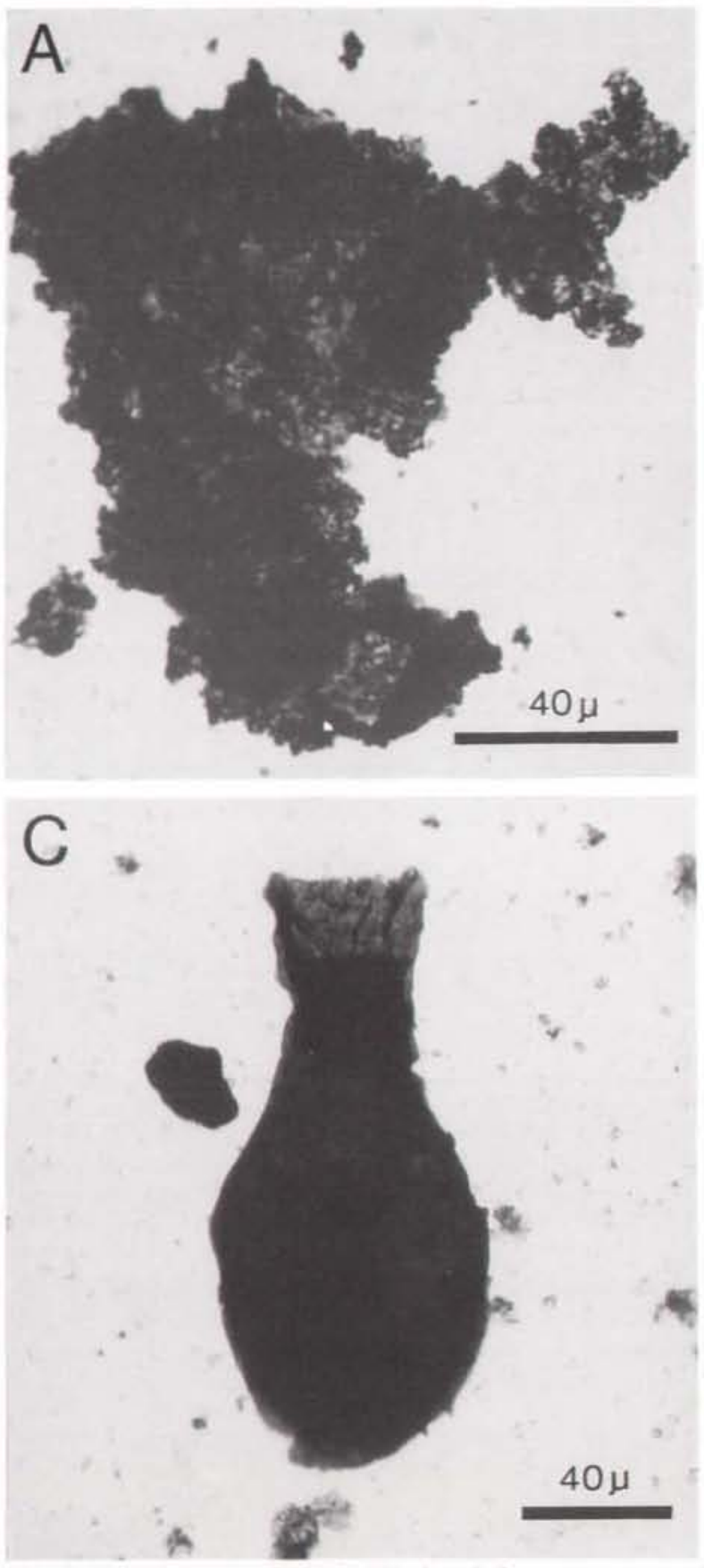

Fig. 8. Organic matter from the Silurian shales.

A. Large particles of amorphous kerogen. GGU 316061-2, Lafayette Bugt Formation, Washington Land. B. Finely disseminated amorphous kerogen. GGU 316490-1, Lafayette Bugt Formation, Nyeboe Land. C. Chitinozoa. GGU 315950-2. Wulff Land Formation, Wulff Land. D. Graptolite fragment. GGU 315950-2. Wulff Land Formation, Wulff Land. slide and in a second slide prepared after sieving the kerogen on a 10 micron nylon mesh. A third slide was made from those samples containing palynomorphs, after weak oxidation.

Systematic information on Thermal Alteration Index (TAI), relative content and composition of kerogen and
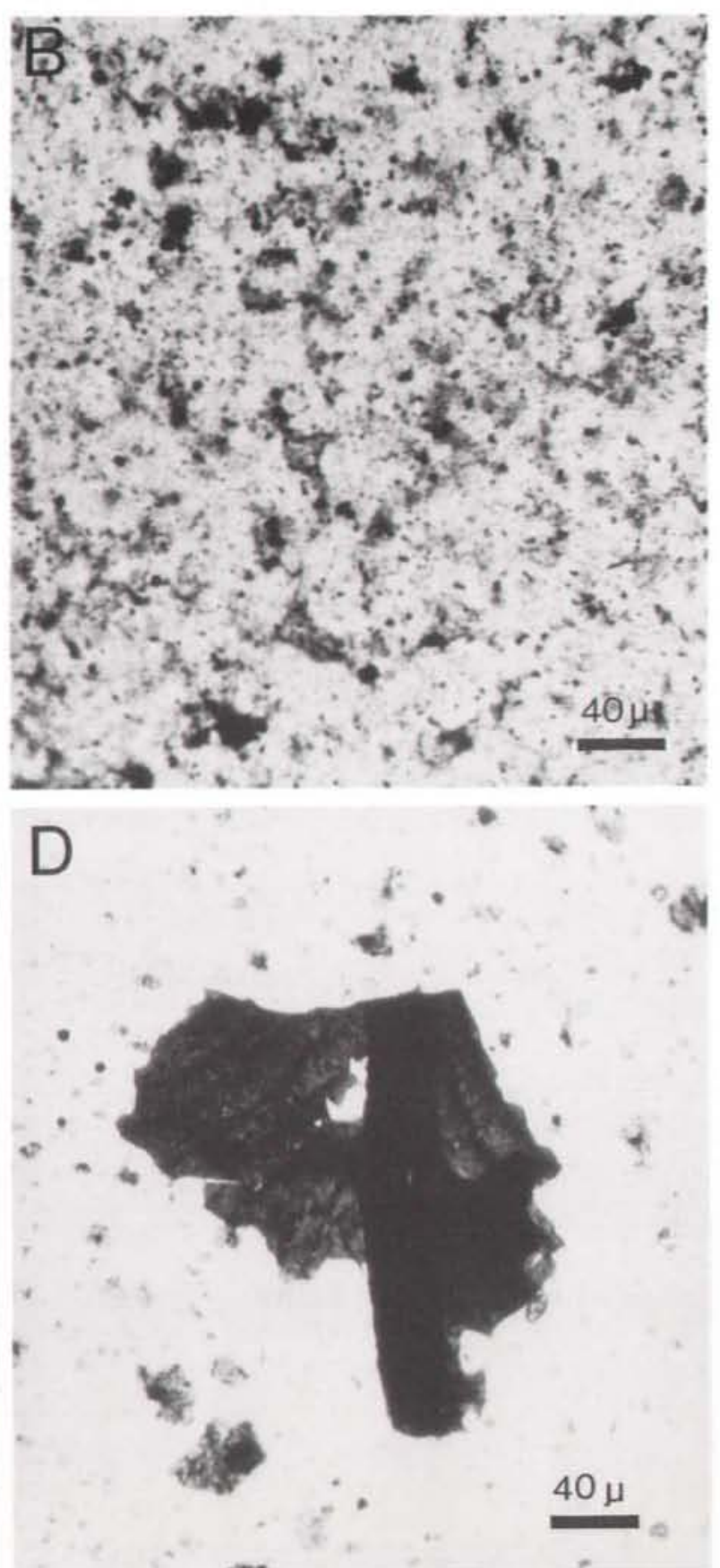
palynomorphs has been achieved from more than 194 samples and 70 core fragments. The TAI value was evaluated from the colour of amorphous kerogen using the scale from 1 to 5 originally proposed for spore coloration (Staplin, 1969). The total content of kerogen is tentatively described as poor $(\mathrm{P})$, moderate $(\mathrm{M})$ or rich (R). The relative amounts of the three visually discerned types of organic matter, (1) amorphous kerogen, (2) finely disseminated amorphous kerogen, (3) palynomorphs, were evaluated employing both the first and second slide (fig. 8 and appendix).

There is good correlation between relative content and composition of the kerogen and TOC values. This is particularly well illustrated in the core material (appendix). Samples with high TOC values $(>3 \%)$ and a rich content of kerogen are dominated by large amorphous kerogen particles ( $>60 \%$ in the non-sieved slide). Samples dominated by finely disseminated amorphous kerogen $(>60 \%$, both in non-sieved and sieved slide) have a poor content of kerogen and display low TOC values $(<$ $1 \%$ ). Intermediate samples with TOC values between $1 \%$ and $3 \%$ and moderate kerogen contents have equal amounts of amorphous kerogen and finely disseminated amorphous kerogen. The content of palynomorphs is lower than $20 \%$ in all samples. Graptolite fragments and chitinozoans are frequent (fig. 8), whereas spherical algae and scolecodonts are found only occasionally.

Group A. The upper part of the shales in this group has a poor to moderate content of kerogen and is dom- inated by finely disseminated amorphous kerogen. The kerogen content is greater in the lower part of the group where it is moderate to rich and dominated by amorphous kerogen (appendix). Palynomorphs, especially graptolites and chitinozoans, occur throughout the group but seem to be most common in the carbonaterich intervals.

Group B. The kerogen content of this group is moderate and with a weak dominance of amorphous kerogen (appendix). Graptolite fragments are common and chitinozoans occur in the carbonate-rich intervals.

Group C. This group has a poor kerogen content and is dominated by finely disseminated amorphous kerogen (appendix). Palynomorphs have a scattered occurrence.

Group $D$. These shales have a poor to moderate content of kerogen and are dominated by finely disseminated amorphous kerogen. Palynomorphs, especially chitinozoans and graptolites, are common.

In summary, it is emphasized that the most organicrich Silurian shales, which also have the highest hydrocarbon potential, are dominated by amorphous kerogen. Although the lack of diagnostic structures makes it difficult, at least in detail, to interpret the precursor of the kerogen, there are strong constraints on the possible origin. The presence of marine palynomorphs and macrofossils combined with the interpretation of an upper to lower slope depositional environment (Hurst \& Surlyk, 1982) point towards an origin from marine orga-

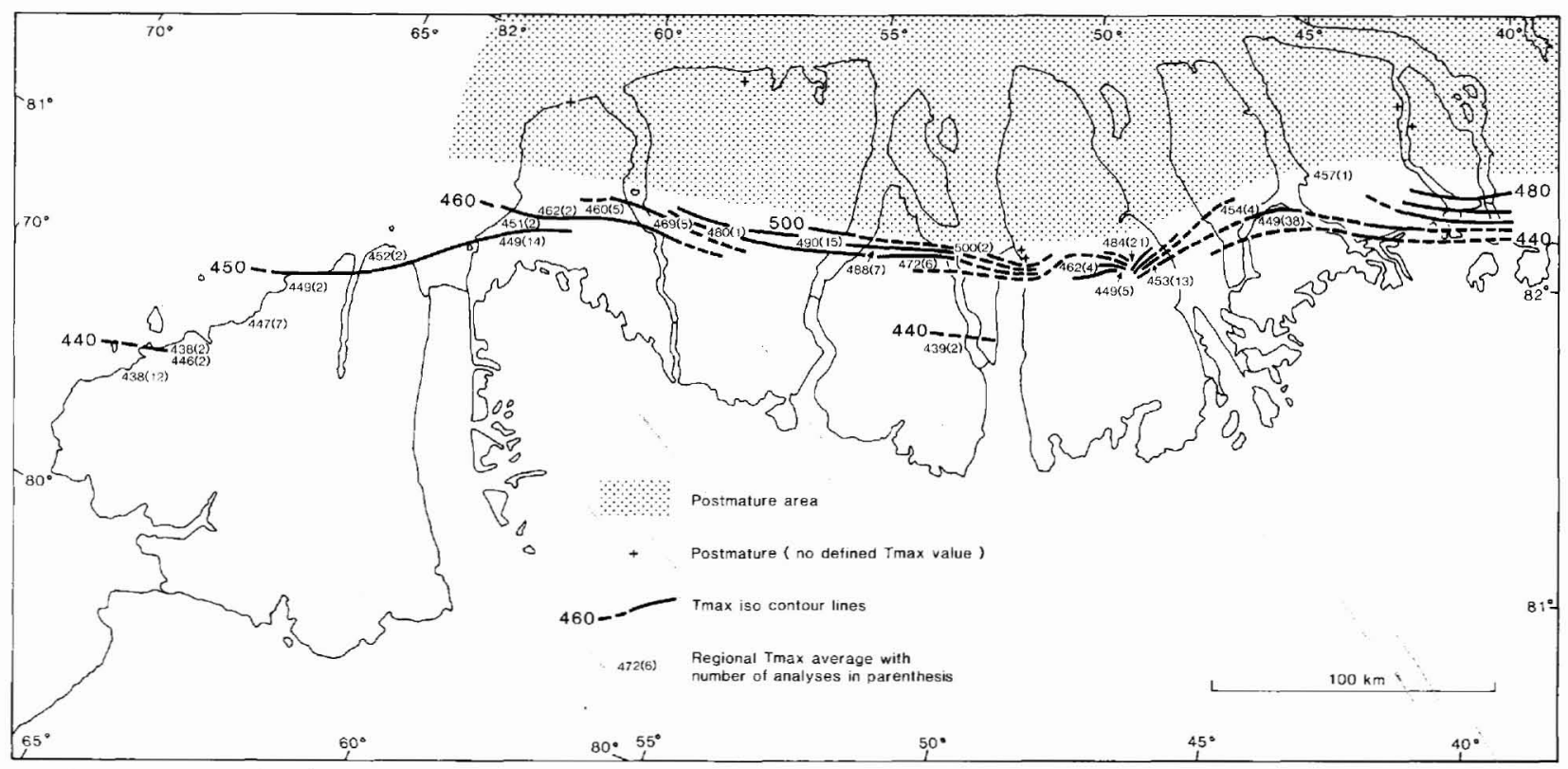

Fig. 9. Averages of measured $T_{\max }$ values (number of values in parenthesis) from the Silurian shales with tentatively drawn contour lines. $T_{\max }$ values of approximately $437^{\circ} \mathrm{C}$ and $460^{\circ} \mathrm{C}$ correspond to the onset and end of petroleum generation, respectively. The crosses indicate samples with non-defined $T_{\max }$ values (postmature). 
nisms, such as algae. This interpretation is supported by the type-II kerogen trend of the early mature organic matter (fig. 16) and the very restricted occurrence of possible terrestrial plant megafossils (Larsen et al., 1987 ) as would be expected in the Silurian when plants were in the very early stage of evolution (Gray, 1985). The algal structure was destroyed during or subsequent to deposition, either by anoxic bacteria or by compaction and thermal alteration. The less organic-rich shales, which are dominated by finely disseminated amorphous kerogen, either represent periods of lower organic productivity or, more probably, periods of higher oxygen content in the water column and consequently intensive biodegradation of the organic matter.

\section{Thermal maturity}

The thermal maturity of the Silurian shales has been evaluated from the $T_{\max }$ value of the Rock Eval pyrolysis and from the TAI value of the palynologically prepared kerogen. More than 275 samples have been analysed with the Rock Eval providing more than 160 reliable $T_{\max }$ values. The large number of samples which did not define any $T_{\max }$ value are either very low in TOC content or are strongly thermally altered. A few samples impregnated with bitumen gave anomalously low $T_{\max }$ values which are not representative of the thermal maturity. Approximately 195 palynological slides from samples and a further 70 from core fragments have been studied with respect to the Thermal Alteration Index.
Usually there is only slight variation in values of $T_{\max }$ or TAI in each core (appendix), section or local area. Consequently, the $T_{\max }$ average value and the dominant TAI value have been employed for further evaluation. There is no major difference in thermal maturity evaluated by the two methods and in both cases it has been possible to prepare a map showing the variation in regional thermal maturity (figs 9 and 10). The present surface exposures of the main Silurian shale belt show a large variation in thermal maturity with respect to hydrocarbon generation, ranging from immature or early mature to completely postmature, or even metamorphic.

The Silurian shales from Washington Land with $T_{\max }$ values below $440^{\circ} \mathrm{C}$ and TAI values of $2-2^{+}$are thermally immature or early mature. In Hall Land and Nares Land, the maturity reflects peak to post-peak generation conditions $\left(T_{\max }: 445-450^{\circ} \mathrm{C}\right.$, TAI: $\left.2^{+}-3^{-}\right)$in the southernmost exposures of the Silurian shales, and late oil generation conditions further north $\left(T_{\max }: 445\right.$ $460^{\circ} \mathrm{C}$, TAI: $3^{-}-3$ ). All Silurian shales in Nyeboe Land, Warming Land, Permin Land and western Wulff Land are thermally postmature $\left(T_{\max }: 470-510^{\circ} \mathrm{C}\right.$ and undefined, TAI: $3^{-}-3^{+}$). In central Wulff Land the shales vary from mature on both sides of the valley north of Apollo $\mathrm{S} \varnothing\left(T_{\max }: 445-455^{\circ} \mathrm{C}\right.$, TAI: $\left.2^{+}-3^{-}\right)$to thermally postmature in the valley itself $\left(T_{\max }: 475-500^{\circ} \mathrm{C}\right.$, TAI: $3-3^{+}$).

The maturity parameters obtained outline a distinct trend of thermal maturity throughout central and west-

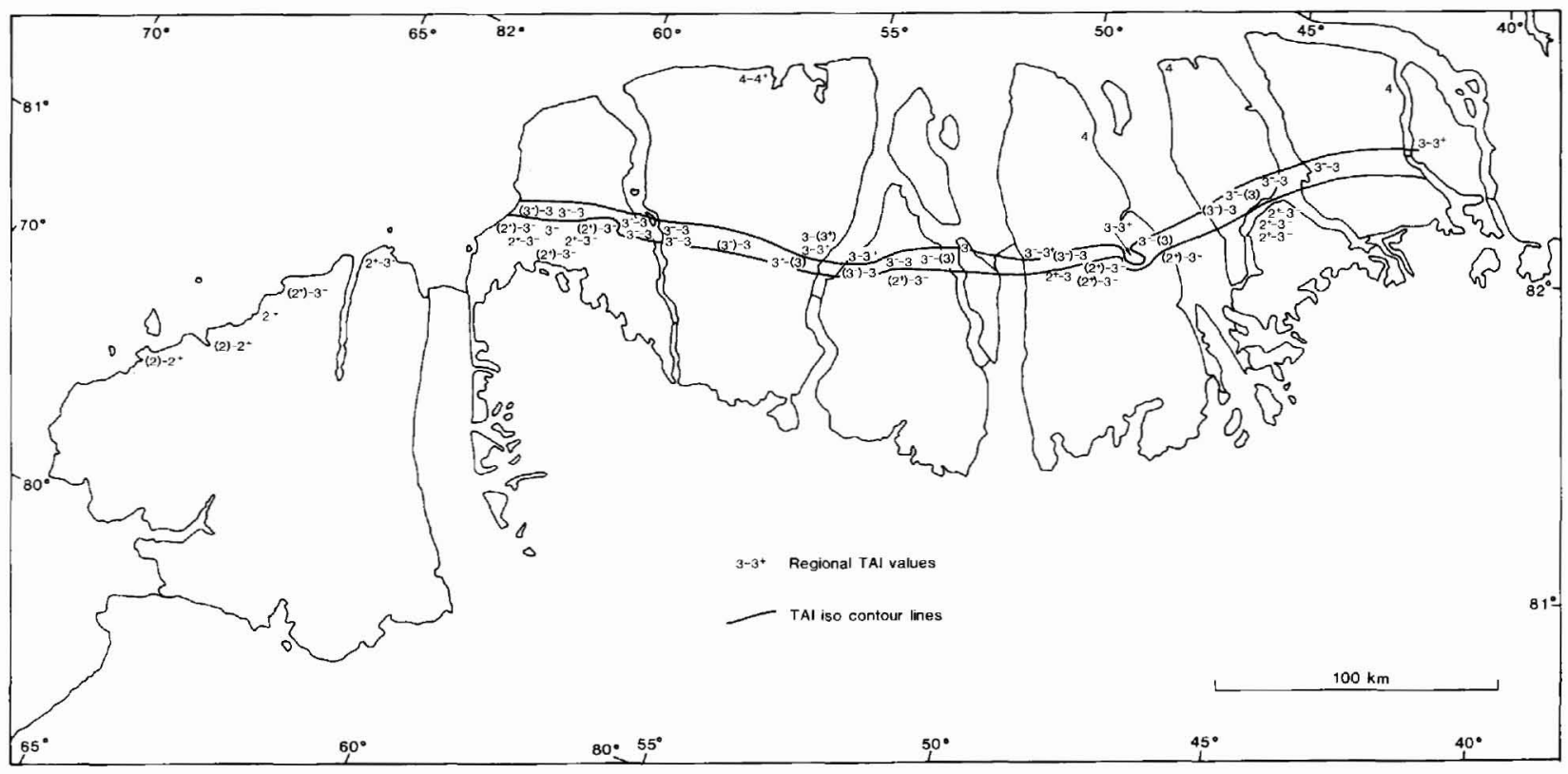

Fig. 10. Measured TAI (Thermal Alteration Index) values from the Silurian shales with tentatively drawn contour lines. Values of $2^{-}$to 2 and $3^{-}$to 3 correspond to the onset and end of petroleum generation, respectively. 
ern North Greenland which is consistent with the pattern indicated by the Cambrian source rocks in Freuchen Land (Christiansen et al., 1987). Towards the north a very large area (roughly coinciding with the lower Llandovery turbidite basin) is completely thermally altered with virtually no hydrocarbons left. A relatively narrow zone, which corresponds to the main outcrop belt of the Silurian shales, marks the transition from (early) mature to postmature conditions during the deepest burial. In the south, a large area comprising mainly Ordovician and Cambrian shelf carbonates is thermally immature to early mature.

\section{Hydrocarbon potential}

The hydrocarbon potential of most of the studied material, expressed as the sum of the $\mathrm{S} 1+\mathrm{S} 2$ values from the Rock Eval, is rather poor, despite the high content of organic carbon (figs 11-14).

The early mature group A shales in Washington Land have a fair to excellent potential (fig. 11). A good correlation between TOC and generation potential is observed (fig. 15); shales with typical values of $2 \%$ and $4 \%$ TOC have potentials of 7 and $16 \mathrm{HC} / \mathrm{g}$ rock, respectively. In Nares Land, where the group A shales are mature, a similar strong correlation is observed but the potential is considerably lower (poor to good) (figs 11 and 15). Shales with $2 \%$ TOC and $4 \%$ TOC have a generation potential of approximately 3.5 and $8 \mathrm{mg}$ $\mathrm{HC} / \mathrm{g}$ rock, respectively. In the remaining part of the region the postmature group A shales have a poor potential and display a less pronounced correlation between TOC and S1 + S2 (figs 11 and 15). Shales with $2 \%$ TOC and $4 \%$ TOC typically show a potential of only 0.5 and $1.5 \mathrm{mg} \mathrm{HC} / \mathrm{g}$ rock, respectively.

The group B shales throughout the region have a poor (to fair) generation potential; in most cases lower than $1 \mathrm{mg} \mathrm{HC} / \mathrm{g}$ rock (fig. 12). Only few samples from the mature area in Nares Land have slightly higher values.

Both the group $\mathrm{C}$ and $\mathrm{D}$ shales have a poor potential with values lower than $2 \mathrm{mg} \mathrm{HC} / \mathrm{g}$ rock (figs 13 and 14).

The data clearly suggest that only the group A shales had a significant source rock potential prior to subsidence and thermal alteration. The low potential of many of these samples (especially in the Wulff Land to eastern Nyeboe Land region) is considered as a maturity effect rather than a compositional effect. The good correlation between TOC and $\mathrm{S} 1+\mathrm{S} 2$ for each rank of maturity (fig. 15) and the lowering of the Hydrogen Index with increasing maturity (fig. 16) may be applied in the interpretation of the hydrocarbon generation of the source rocks.
The early mature source rocks from Washington Land $\left(T_{\max }=438^{\circ} \mathrm{C}\right)$ have generated minor amounts of hydrocarbons which locally have migrated into interbedded conglomerates (Christiansen \& Rolle, 1985, fig. 6). The values of the Hydrogen Index (fig. 16), assuming an original type II composition of the kerogen, suggest that less than $25 \%$ of the potential hydrocarbons have been generated and expelled. The mature source rocks in Nares Land $\left(T_{\max }=449^{\circ} \mathrm{C}\right)$ have generated and expelled more than $50 \%$ of their potential but a significant residual potential still remains. In contrast, the remaining postmature samples $\left(T_{\max }=477^{\circ} \mathrm{C}\right)$ have no residual potential, all hydrocarbons having been expelled or cracked.

These values indicate that very large amounts of hydrocarbons were generated in the group A shales before and during the time of deepest subsidence and strongest thermal alteration. The hydrocarbons generated north of the $460^{\circ} T_{\max }$ isoline (fig. 9) have either been thermally degraded or have migrated upwards or southwards to less mature reservoirs where they might have been trapped. A comparison of the spatial relations of potential reservoirs, such as Silurian turbidite sandstone or Silurian carbonate reefs and the thermal maturity maps (figures 9 and 10), shows that most of these potential traps have been eroded away or are buried only a few hundred metres below the present-day topographic surface.

\section{Conclusions}

From the present study of the Silurian shales of central and western North Greenland the following main conclusions concerning the petroleum geology can be drawn.

1) Although sedimentation of shales took place during most of the Silurian period in North Greenland, deposition of organic-rich units was restricted in both time and space.

2) Potential hydrocarbon source rocks formed when and where black shales were laid down over wide areas of shallow-water carbonates.

3) Source rock deposition started in the middle Llandovery in Washington Land and continued through the late Llandovery in the entire region covering an area of more than $10000 \mathrm{~km}^{2}$.

4) None of the shales of Wenlock and Ludlow age contain sufficient organic matter to be considered as potential source rocks.

5) The organic matter in the source rocks is dominated by large amorphous kerogen particles, probably with marine algae as precursor. 


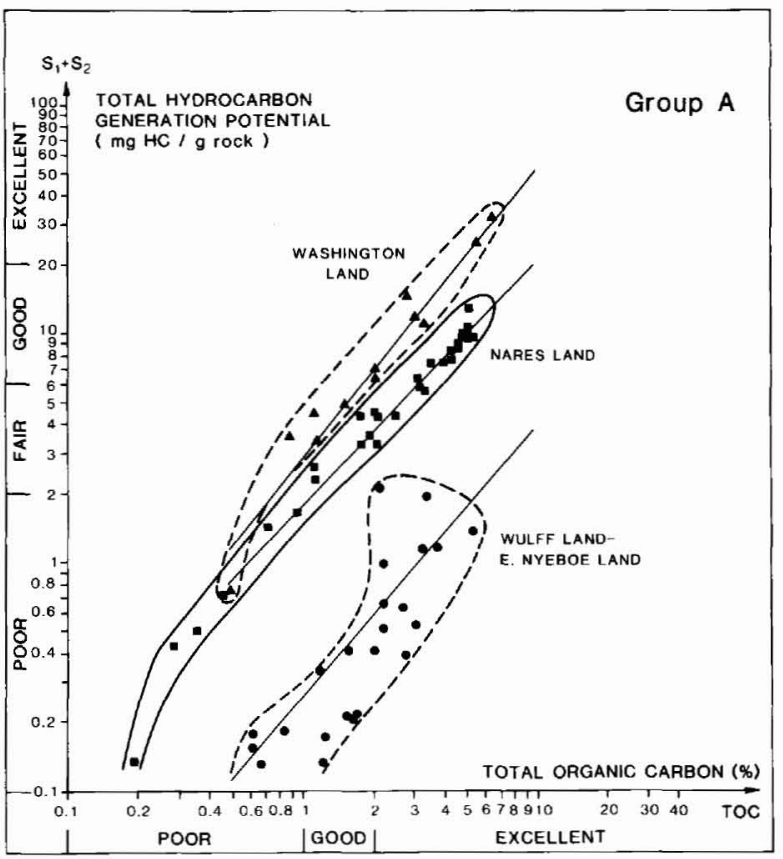

Fig. 11. Plot of Total Organic Carbon (TOC) versus Total Hydrocarbon Generation Potential $(\mathrm{S} 1+\mathrm{S} 2)$ for the group A shales.

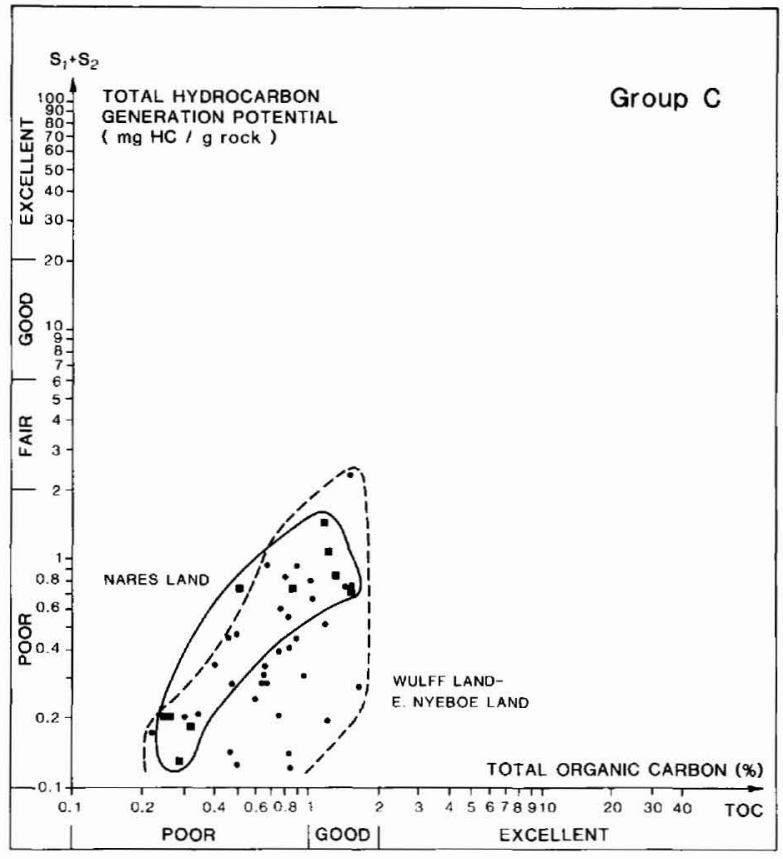

Fig. 13. Plot of Total Organic Carbon (TOC) versus Total Hydrocarbon Generation Potential $(\mathrm{S} 1+\mathrm{S} 2)$ for the group C shales.

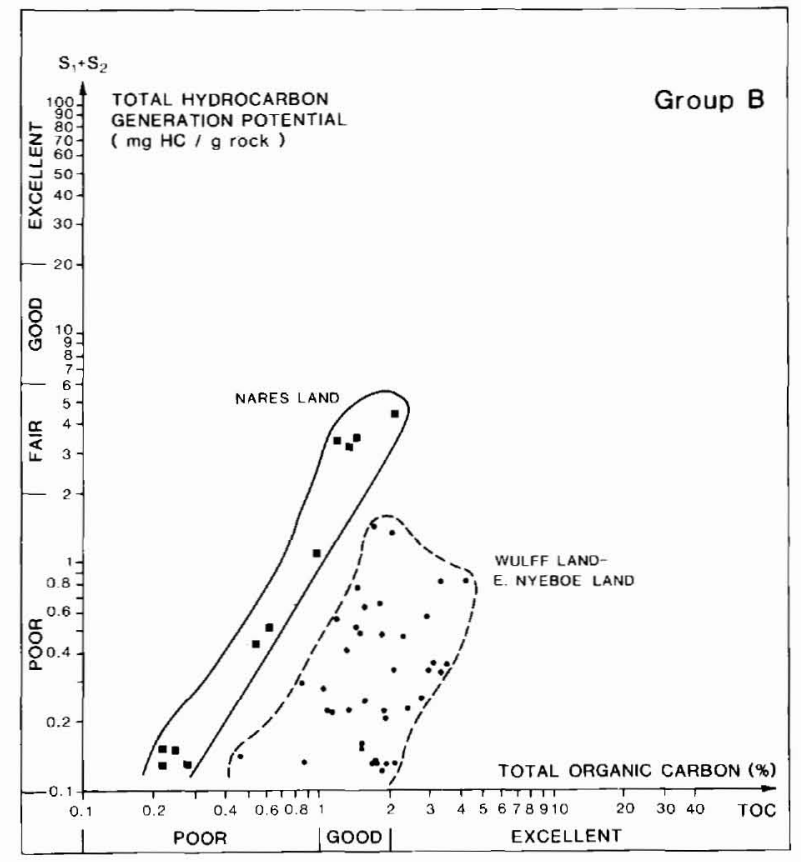

Fig. 12. Plot of Total Organic Carbon (TOC) versus Total Hydrocarbon Generation Potential $(\mathrm{S} 1+\mathrm{S} 2)$ for the group B shales.

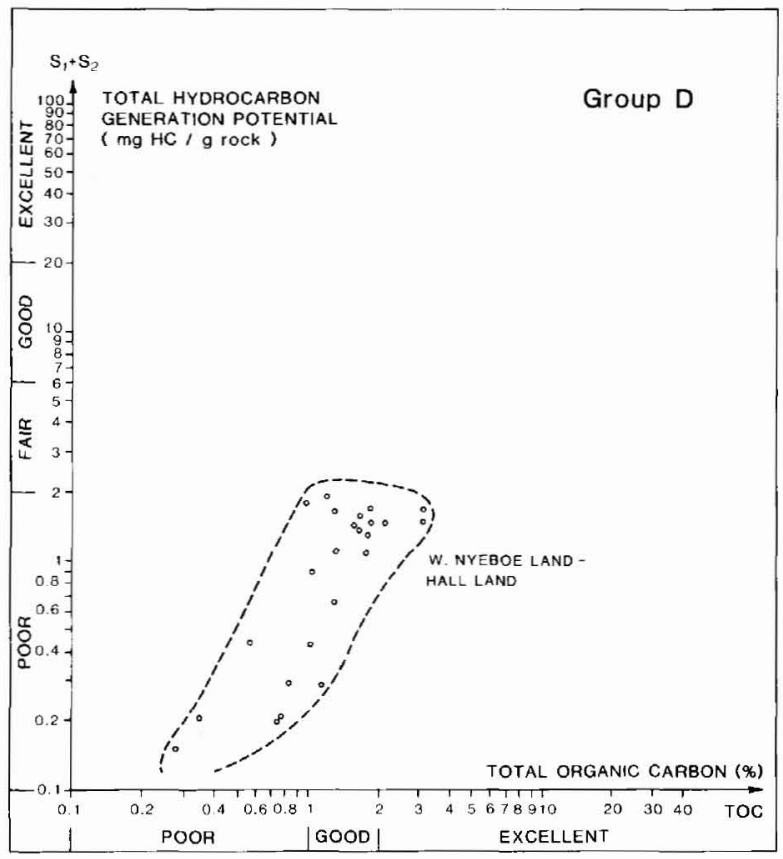

Fig. 14. Plot of Total Organic Carbon (TOC) versus Total Hydrocarbon Generation Potential $(\mathrm{S} 1+\mathrm{S} 2)$ for the group D shales. 


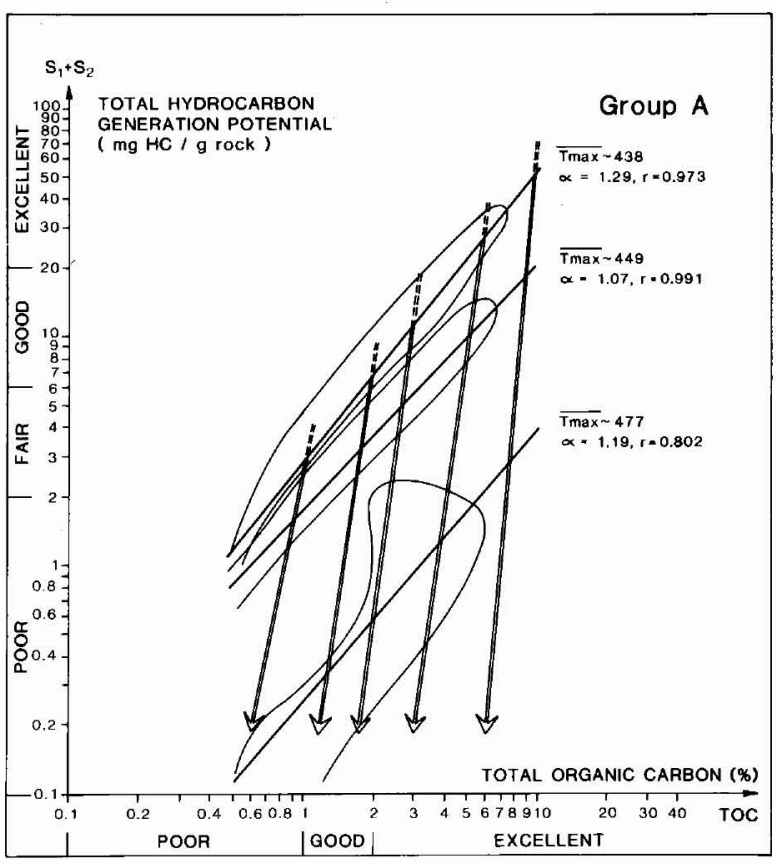

Fig. 15. Correlation between Total Hydrocarbon Generation Potential (S1 + S2) and Total Organic Carbon (TOC) for various ranks of maturity. The arrows tentatively indicate the generation history of the source rocks during thermal maturation based on a $50 \%$ loss of carbon during complete maturation.

6) The source rocks are oil-prone with typical TOC values between $2 \%$ and $6 \%$ and a generative hydrocarbon potential up to $30 \mathrm{mg} \mathrm{HC} / \mathrm{g}$ rock. The cumulative source rock thickness is between 80 and $130 \mathrm{~m}$; the good to excellent source rocks have a thickness of less than 40 $\mathrm{m}$.

7) Thermal maturity mapping of surface rocks employing $T_{\max }$ and TAI values defines a distinct and regionally consistent change from north to south.

8) Most of the subcropping and a major portion of the outcropping source rocks are thermally postmature (or even low metamorphic) with respect to oil generation.

9) A relatively narrow zone, 10 to $30 \mathrm{~km}$ wide, contains mature source rocks. Migrated and trapped hydrocarbons might, at least from a thermal point of view, be preserved in this zone.

10) The southern part of the region is thermally immature to early mature. It contains, however, no known deeply buried source rocks, and occasionally has only a thin cover of Silurian shales. Possible oil accumulations with a Silurian source rock would need to have migrated into stratigraphically much deeper levels, probably during the Ellesmerian orogeny, in order to be preserved.

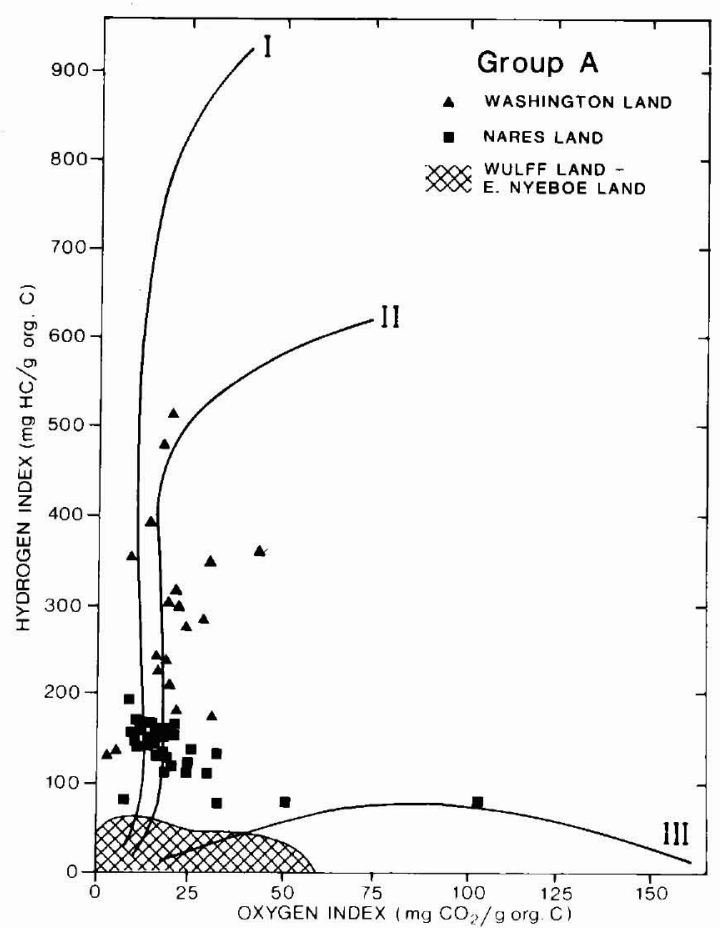

Fig. 16. Plot of Hydrogen Index versus Oxygen Index (modified van Krevelen diagramme) for the group A shales.

It is not considered likely that these constraints have been fulfilled, and the hydrocarbon potential of the Silurian sequence in North Greenland is regarded as low.

Acknowledgements. Project 'Nordolie' was supported by the Danish Ministry of Energy through project no. EFP 83-2251305. J. Bojesen-Koefoed, J. Boserup, A. Clausen, K. Z. Jørgensen, $O$. Nygaard, O. Nykjær, and F. Rolle are thanked for assistance in the field. We are grateful to M. Bjerreskov for identification of the graptolites. P.-H. Larsen, F. Surlyk, and M. Sønderholm discussed many aspects of the Silurian geology and commented on an early draft of the paper. J. Halskov, B. S. Hansen, B. Larsen and M. Larsen assisted with the technical preparation of the manuscript.

\section{References}

Balkwill, H. R. 1978: Evolution of Sverdrup Basin, Arctic Canada. Bull. Am. Ass. Petrol. Geol. 62, 1004-1028. 
Bjerreskov, M. 1981: Silurian graptolites from Washington Land, western North Greenland. Bull. Grønlands geol. Unders. 142, 58 pp.

Bjerreskov, M. 1986: Silurian graptolites from N Greenland. In Hughes, C. P. \& Rickards, R. B. (edit.) Palaeoecology and biostratigraphy of graptolites. Spec. Publ. Geol. Soc. 20, 181-189.

Christiansen, F. G. \& Rolle, F. 1985: Project 'Nordolie': hydrocarbon source rock investigations in central North Greenland. Rapp. Grønlands geol. Unders. 125, 17-21.

Christiansen, F. G., Nøhr-Hansen, H., Rolle, F. \& Wrang, P. 1985: Preliminary analysis of the hydrocarbon source rock potential of central and western North Greenland. Rapp. Grønlands geol. Unders. 126, 117-128.

Christiansen, F. G., Nykjær, O. \& Nøhr-Hansen, H. 1986: Source rock investigations and shallow core drilling in central and western North Greenland - project 'Nordolie'. Rapp. Grønlands geol. Unders. 130, 17-23.

Christiansen, F. G., Nøhr-Hansen, H. \& Nykjær, O. 1987: The Cambrian Henson Gletscher Formation: a mature to postmature hydrocarbon source rock sequence from North Greenland. Rapp. Grønlands geol. Unders. 133, 141-157.

Dawes, P. R. 1976: Precambrian to Tertiary of northern Greenland. In Escher, A. \& Watt, W. S. (edit.) Geology of Greenland, 248-303. Copenhagen: Geol. Surv. Greenland.

Escher, J. C. \& Larsen, P.-H. 1987: The buried western extension of the Navarana Fjord escarpment in central and western North Greenland. Rapp. Grønlands geol. Unders. 133, 81-89.

Gray, J. 1985: The microfossil record of early land plants: advances in understanding of early terrestrialization, 19701984. Phil. Trans R. Soc. London B 309, 167-195.

Håkansson, E. \& Stemmerik, L. 1984: Wandel Sea Basin - The North Greenland equivalent to Svalbard and the Barents Sea. In Spencer, A. M. et al. (edit.) Petroleum geology of the North European margin, 97-107. Graham \& Trotman for the Norwegian Petroleum Society.

Henriksen, N. 1985: Systematic geological mapping in 1984 in central and western North Greenland. Rapp. Grønlands geol. Unders. 126, 5-10.

Henriksen, N. 1987: Systematic geological mapping in 1985 in central and western North Greenland. Rapp. Gronlands geol. Unders. 133, 5-12.

Higgins, A. K., Mayr, U. \& Soper, N. J. 1982: Fold belts and metamorphic zones of northern Ellesmere Island and North Greenland. In Dawes, P. R. \& Kerr, J. W. (edit.) Nares Strait and the drift of Greenland: a conflict in plate tectonics. Meddr Grønland Geosci. 8, 159-166.

Higgins, A. K., Ineson, J. R., Peel, J. S., Surlyk, F. \& Sønderholm, M. in press: The Franklinian basin in North Greenland. In Trettin, H. P. (edit.) The Innuitian region. Decade of North American Geology E,
Hurst, J. M. 1980: Silurian stratigraphy and facies distribution in Washington Land and western Hall Land, North Greenland. Bull. Grønlands geol. Unders. 138, 95 pp.

Hurst, J. M. \& Surlyk, F. 1982: Stratigraphy of the Silurian turbidite sequence of North Greenland. Bull. Grønlands geol. Unders. 145, $121 \mathrm{pp}$

Larsen, P.-H., Edwards, D. \& Escher, J. C. 1987: Late Silurian plant megafossils from the Peary Land Group, western North Greenland. Rapp. Gronlands geol. Unders. 133, 107112.

Larsen, P.-H. \& Escher, J. C. 1985: The Silurian turbidite sequence of the Peary Land Group between Newman Bugt and Victoria Fjord, western North Greenland. Rapp. Grønlands geol. Unders. 126, 47-67.

Larsen, P.-H. \& Escher, J. C. 1987: Additions to the lithostratigraphy of the Peary Land Group in western and central North Greenland. Rapp. Grønlands geol. Unders. 133, 65-80.

Norford, B. S. 1972: Silurian stratigraphic sections at Kap Tyson, Offley $\varnothing$ and Kap Schuchert, northwestern Greenland. Meddr Grønland 195(2), 40 pp.

Peel, J. S. \& Hurst, J. M. 1980: Late Ordovician and early Silurian stratigraphy of Washington Land, western North Greenland. Rapp. Grønlands geol. Unders. 100, 18-23.

Sønderholm, M., Harland, T., Due, P. H., Jørgensen L. N. \& Peel, J. S. 1987: Lithostratigraphy and depositional history of Upper Ordovician-Silurian shelf carbonates in central and western North Greenland. Rapp. Grønlands geol. Unders. 133, 27-40.

Soper, N. J., Dawes, P. R. \& Higgins, A. K. 1982: CretaceousTertiary magmatic and tectonic events in North Greenland and the history of adjacent ocean basins. In Dawes, P. R. \& Kerr, J. W. (edit.) Nares Strait and the drift of Greenland: a conflict in plate tectonics. Meddr Grønland Geosci. 8, 205220.

Staplin, F. L. 1969: Sedimentary organic matter, organic metamorphism, and oil and gas occurrence. Bull. Can. Petrol. Geol. 17, 47-66.

Surlyk, F. \& Hurst, J. M. 1983: Evolution of the early Paleozoic deep-water basin of North Greenland - Aulacogen or narrow ocean? Geology 11, 77-81.

Surlyk, F. \& Hurst, J. M. 1984: The evolution of the early Paleozoic deep-water basin of North Greenland. Bull. geol. Soc. Am. 95, 131-154.

Surlyk, F. \& Ineson, J. R. 1987: Aspects of Franklinian shelf, slope and trough evolution and stratigraphy in North Greenland. Rapp. Grønlands geol. Unders. 133, 41-58.

Trettin, H. P. \& Balkwill, H. 1979: Contributions to the tectonic history of the Innuitian Province, Arctic Canada. Can. J. Earth Sci. 16, 748-769. 


\section{APPENDIX}

Sedimentary logs of the six Silurian cores

D. (318007), $F_{1}$ (GGU 318008), $F_{2}$ (GGU 318009), $F_{3}$ (GGU 318010 ), $N_{1}$ (GGU 318012), $N_{2}$ (GGU 318013), with analytical data. See fig. 1 for location. The gamma ray $\log$ is indicated as counts per minute with the following conditions: an integration time of 5 seconds, a crystal size of 1 inch, a diameter of $42 \mathrm{~mm}$, and a $\log$ speed of 1.5 metre per minute. TIC $=$ Total Inorganic
Carbon, TOC $=$ Total Organic Carbon, $T_{\max }$ is measured from the Rock Eval pyrolysis, TAI = Thermal Alteration Index, KEROG is the kerogen classification (dotted: finely disseminated amorphous kerogen, black: large amorphous kerogen particles, white: palynomorphs). $\mathrm{R}, \mathrm{M}$ and $\mathrm{P}$ correspond to a rich, moderate and poor content of kerogen, respectively.

\section{LEGEND}

Lithology
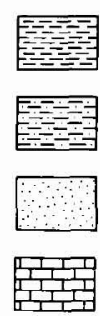

Shale

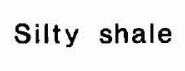

Sandstone

Limestone

\section{Structure}

Dolomite

Chert

Interlayered

calcarenites

Heterolith

(interlaminated

shale and limestone) \begin{tabular}{lll}
\hline & 0 \\
0 & 0 \\
0
\end{tabular}

- Massive with clasts (mud supported)

Laminated shale

Parallel laminated

Wavy laminated

Nodular

Massive $\sim \sim$ slumps

$\because$ Mud Flakes

${ }^{\circ}$ Concretions

s, Burrowed 


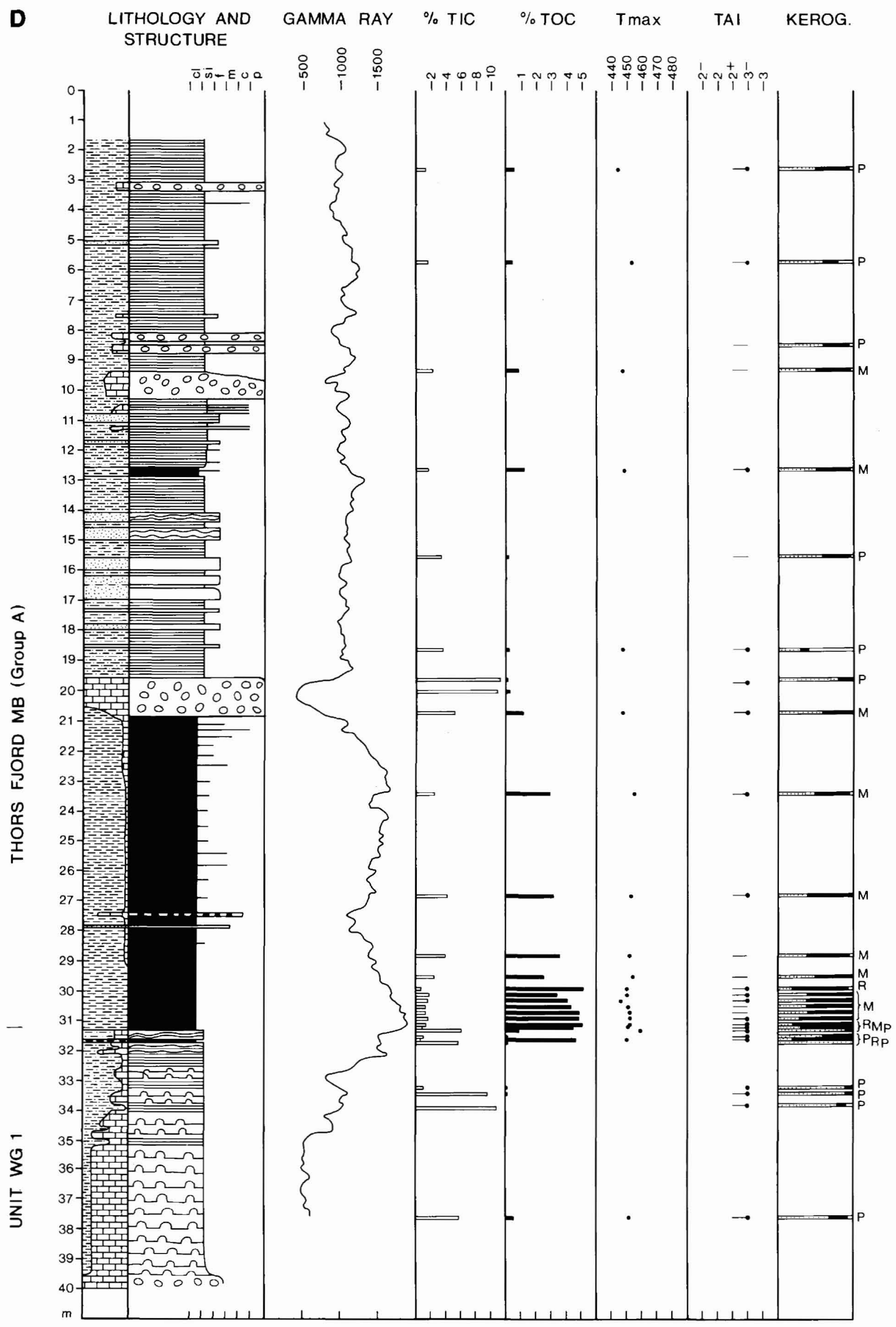




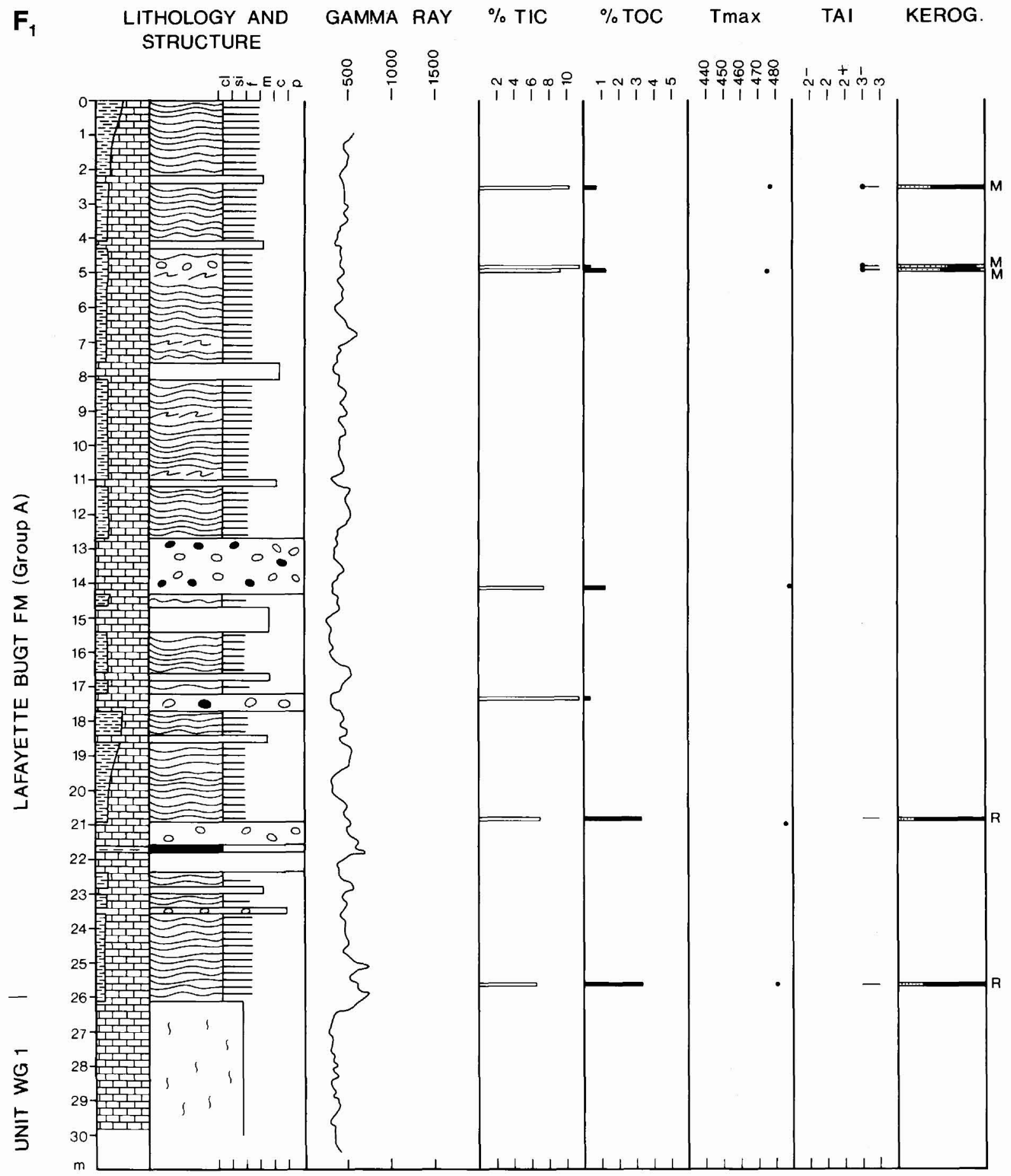


$\begin{array}{llllll}\mathbf{F}_{2} & \text { LITHOLOGY AND } \\ \text { STRUCTURE } & \% \text { TIC } & \% \text { TOC } & \text { T max } & \text { TAI } & \text { KEROG. }\end{array}$

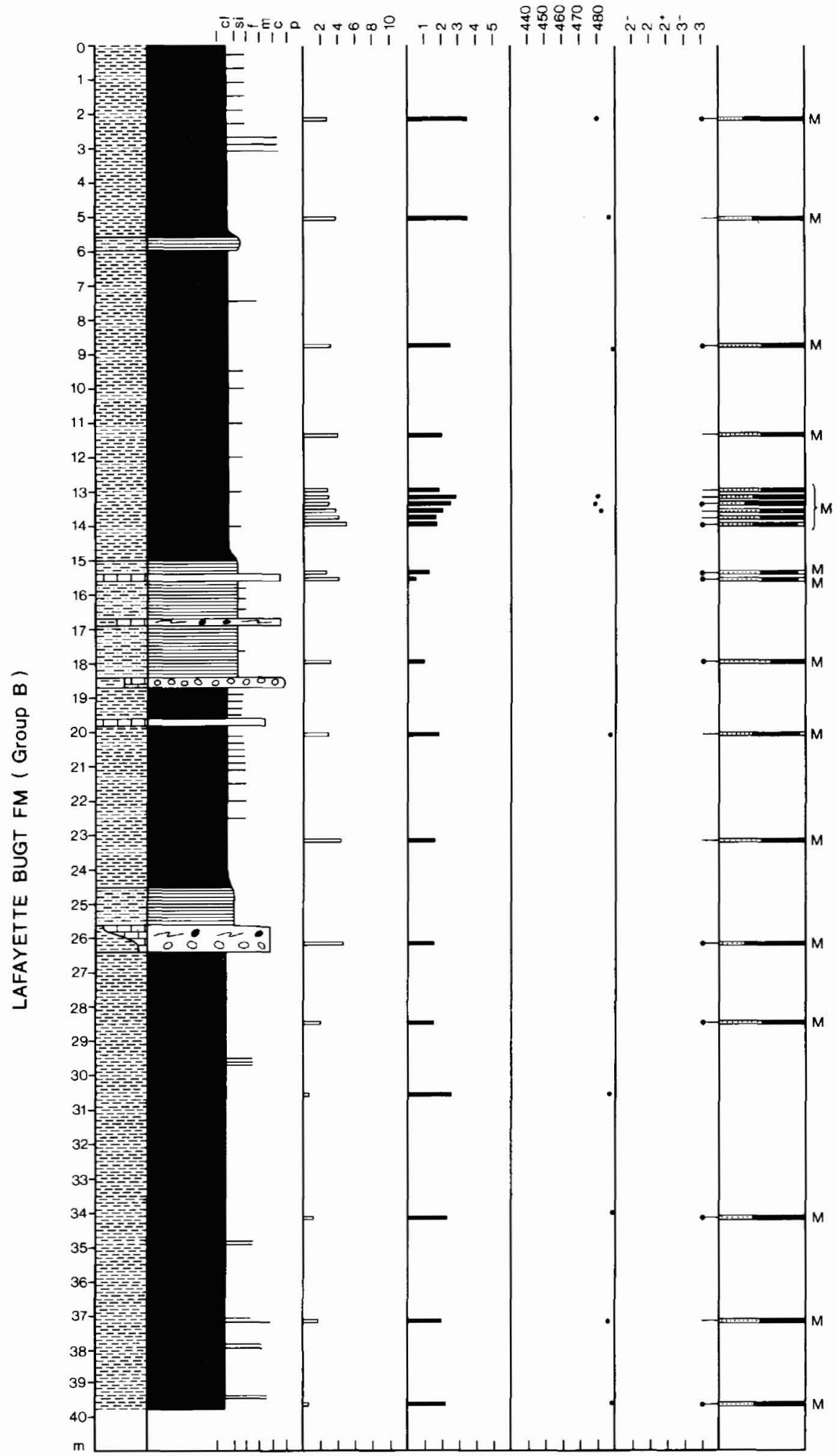




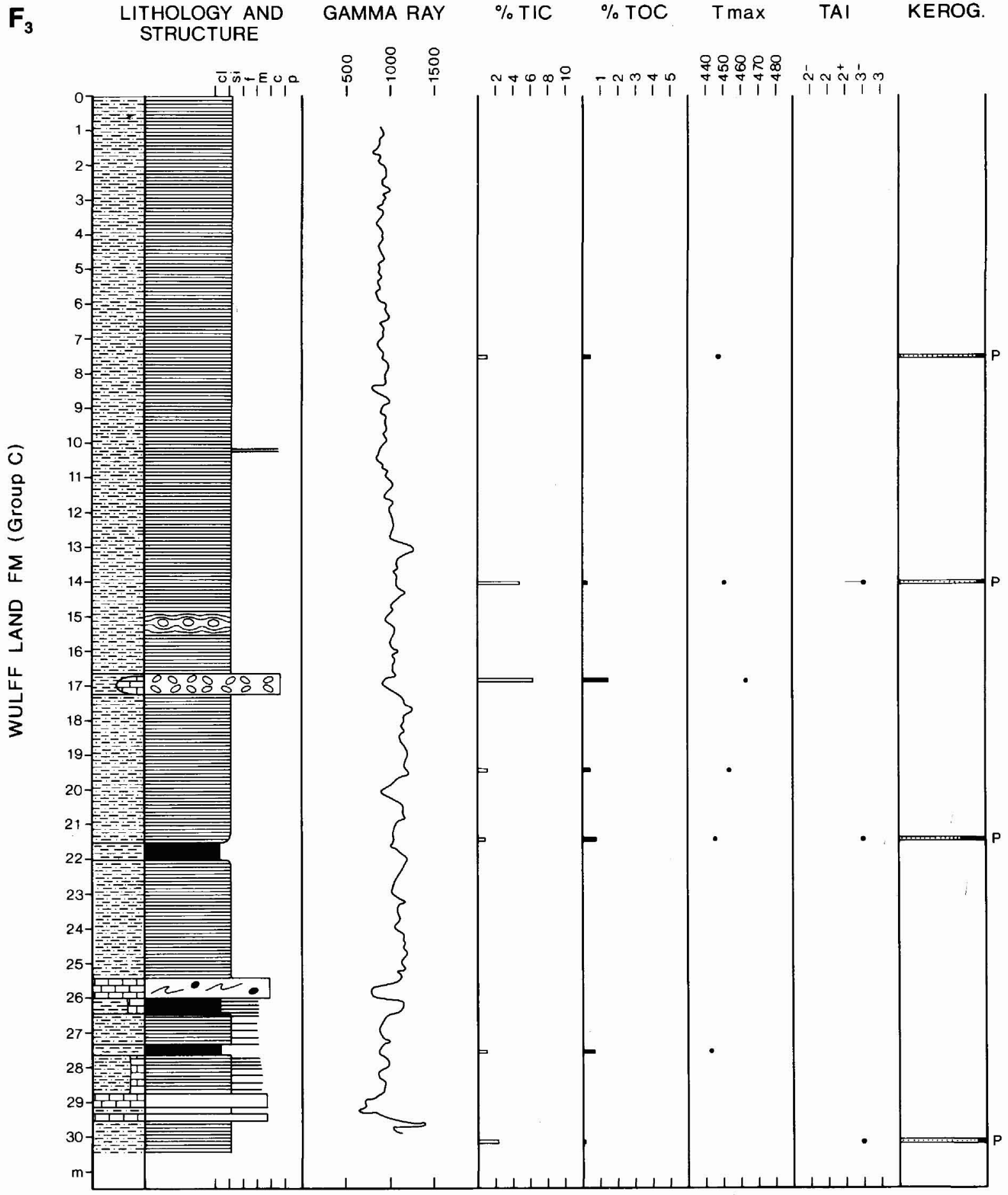




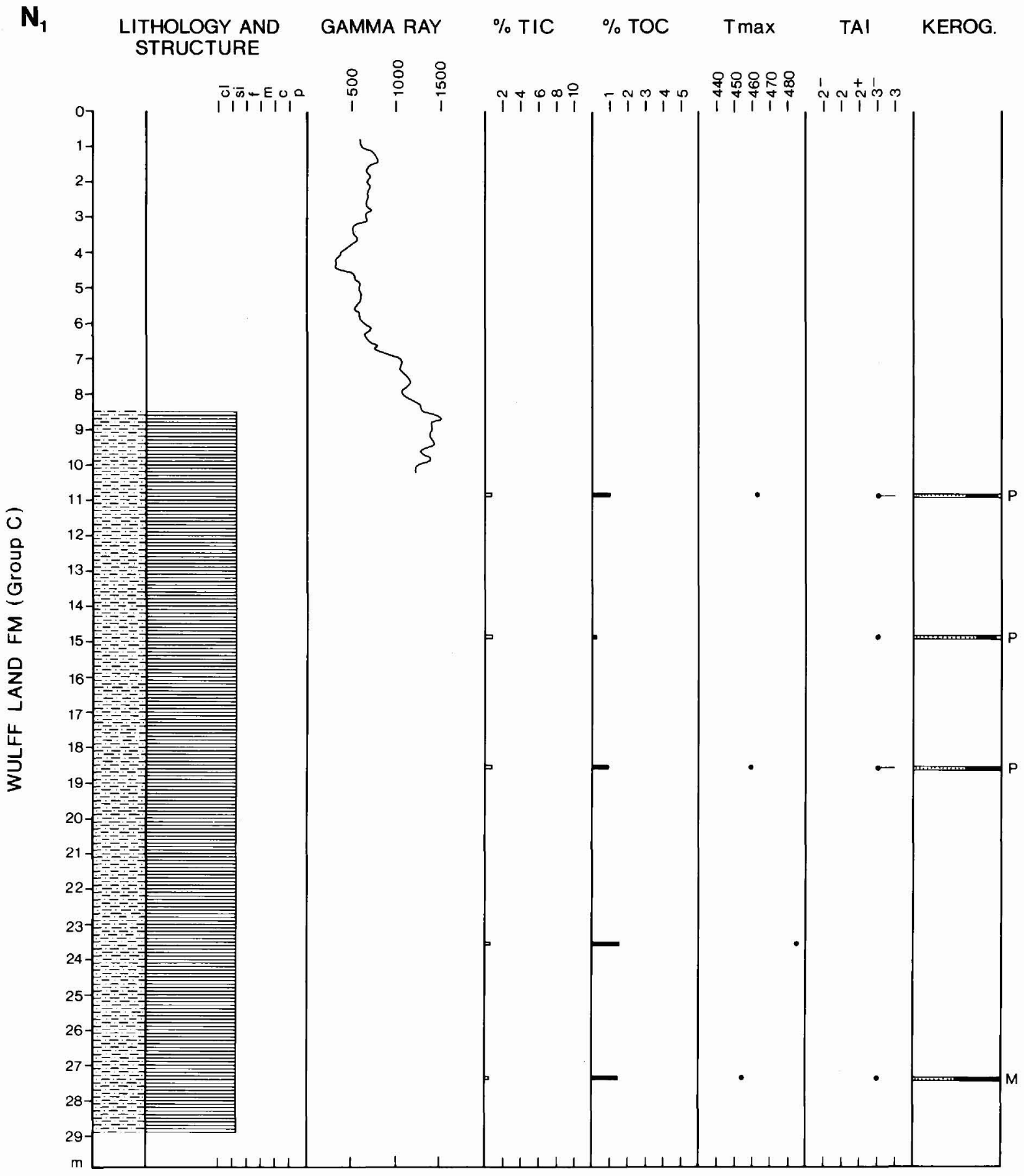




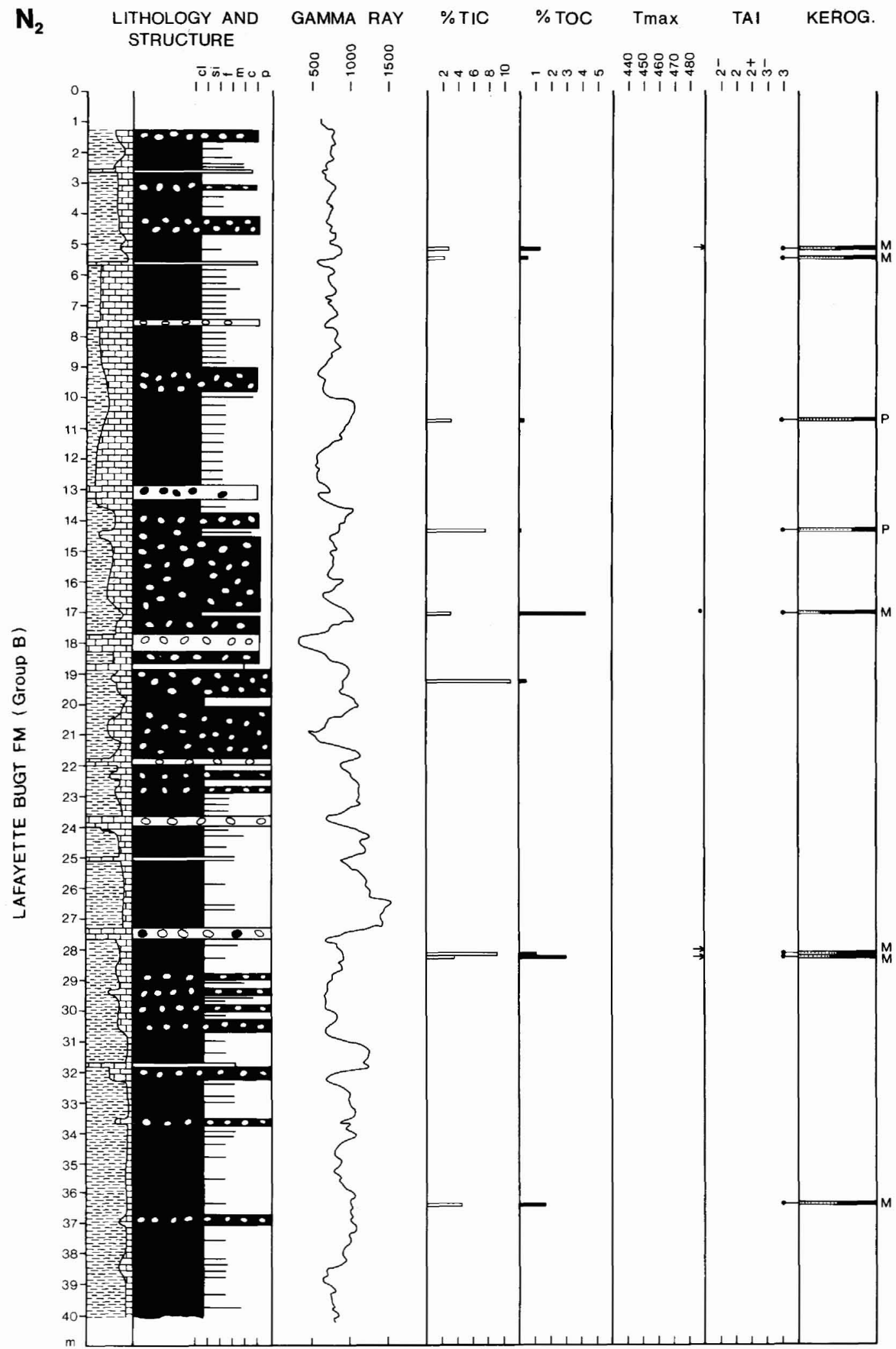

